\title{
First molecular assessment of the interrelationships of cladorchiid digeneans (Digenea: Paramphistomoidea), parasites of Neotropical fishes, including descriptions of three new species and new host and geographical records
}

\author{
Camila Pantoja ${ }^{1,2}$, Tomáš Scholz ${ }^{2}$, José Luis Luque ${ }^{3}$ and Arlene Jones ${ }^{4}$
}

\author{
${ }^{1}$ Programa de Pós-graduação em Ciências Veterinárias, Universidade Federal Rural do Rio de Janeiro (UFRRJ), Seropédica, RJ, Brazil; \\ ${ }^{2}$ Institute of Parasitology, Biology Centre of the Czech Academy of Sciences, České Budějovice, Czech Republic; \\ ${ }^{3}$ Departamento de Parasitologia Animal, UFRRJ, Seropédica, RJ, Brazil; \\ ${ }^{4}$ Creigiau Llwydion, Heol y Maes, Coelbren, Neath, UK
}

\begin{abstract}
The first molecular assessment of phylogenetic relationships of cladorchiid digeneans (superfamily Paramphistomoidea Fischoeder, 1901) from freshwater fishes based on 28S rDNA, ITS2 and cox1 sequences reveals the subfamilies Dadayiinae Fukui, 1929 and Kalitrematinae Travassos, 1933 as non-monophyletic, whereas Dadaytrema Travassos, 1931 represented by three species is monophyletic. Fourteen species of cladorchiids were found in characiform, perciform and siluriform fishes in the Neotropical Region (Brazil and Peru), with numerous new host and geographical records. The first scanning electron micrographs of seven species are presented. Two new species of dadayiine and one new species of kalitrematine paramphistomes are described. Microrchis macrovarium sp. n. from Pimelodella cristata (Müller et Troschel) (type host), Tetranematichthys quadrifilis (Kner) and Pterodoras granulosus (Valenciennes) in Brazil and Peru differs from all three congeners in that the testes are directly tandem, not oblique, and that the ovary, between the caecal ends, is widely separated from the testes. Pronamphistoma philippei sp. n. from Heros sp. in Brazil is distinguished from the type and only species, Pronamphistoma cichlasomae Thatcher, 1992, by the absence of the anterior collar-like expansion present in the type species, the presence of extramural rather than intramural pharyngeal sacs, and the unusual development of the dorsal and ventral exterior circular muscle fibre series in the acetabulum. Pseudocladorchis romani sp. n. from P. granulosus (type host), Brachyplatystoma vaillantii (Valenciennes), Calophysus macropterus (Lichtenstein), Megalodoras uranoscopus (Eigenmann et Eigenmann) and Oxydoras niger (Valenciennes) in Brazil and Peru, is most similar to Pseudocladorchis nephrodorchis Daday, 1907 but differs in the shape of the testes (irregular, versus reniform in the latter species) and the size of the ovary (as large as, or larger than, the testes in the new species). The generic diagnosis of Pronamphistoma Thatcher, 1992 is amended. Dadaytremoides parauchenipteri Lunaschi, 1989 is transferred to Doradamphistoma Thatcher, 1979 as D. parauchenipteri (Lunaschi, 1989) comb. n. based on morphological and molecular evidence.
\end{abstract}

Keywords: Trematoda, diversity, taxonomy, new species, SEM, 28S rDNA, ITS2, cox1, Characiformes, Siluriformes, Cichlidae, South America

The Paramphistomoidea Fischoeder, 1901 is a superfamily of digeneans of cosmopolitan distribution characterised by the absence of an oral sucker and by the posterior position of the acetabulum. They constitute one of the most important groups of helminth parasites of ruminants with a broad spectrum of definitive hosts, and a wide geographical distribution (Sey 2005). They are classified in 12 families and are found in all groups of vertebrates, being common in fresh- and brackish-water fishes (Jones 2005a), although they are curiously rare in Nearctic and Palaearctic freshwater fishes. Various species have veterinary importance, especially members of the Paramphistomidae Fischoeder, 1901 and Gastrothylacidae Stiles et Goldberger,
1910, which cause a disease called paramphistomiasis among ruminants (Sanabria and Romero 2008).

In South America, species of the Cladorchiidae Fischoeder, 1901, Diplodiscidae Cohn, 1904 and Zonocotylidae Yamaguti, 1903 parasitise freshwater fish, the cladorchiids having the second largest species richness among fish digeneans in this continent (Thatcher 2006). Most species were described from fishes in the Amazon River Basin (almost exclusively from Brazil - Thatcher 2006). So far, 35 species are known in 24 genera in South American freshwater fishes (Choudhury et al. 2016, Pantoja et al. 2018), but the validity of some species should be confirmed because their species descriptions were insuf- 
ficient or based on poor-quality, often strongly flattened, contracted or decomposed specimens. Most studies on cladorchiids have been limited to morphological descriptions without the use of scanning electron microscopy (SEM) to document surface ultrastructure.

Molecular phylogenetic studies on paramphistomes are scarce and are almost exclusively limited to taxa of veterinary importance, i.e. species of the Paramphistomidae (Laidemitt et al. 2010, Lotfy et al. 2010, Sokolov et al. 2016, Vélez et al. 2018). In contrast, no molecular data on any Neotropical cladorchiid species from fish are available to assess their relationships. The monophyly of cladorchiid subfamilies has also not been tested using molecular phylogenetic approaches.

During surveys of the helminth parasites of freshwater fishes in Brazil and Peru carried out by the present authors and their collaborators from 2004 until 2018, extensive material of cladorchiid digeneans was collected. In addition to three new species in two new genera recently described by Pantoja et al. (2018) from Peruvian Amazonia, the new material reveals other new species and numerous new host and geographical records. Moreover, this material enabled us to make the first attempt to assess phylogenetic relationships within this family using three different molecular markers. Scanning electron micrographs (SEM) of several taxa are also provided for the first time to document their three-dimensional appearance and visualise details of their surface ultrastructure.

\section{MATERIALS AND METHODS}

\section{Collection of material}

Freshwater fishes from the Amazon River and its tributaries around Iquitos, Loreto Region, Peru were examined in 2004 2006, 2008, 2009, 2011 and 2018, and those from several regions of Brazil (states of Amapá, Mato Grosso do Sul, Pará, Paraná, Rondônia and Tocantins, i.e. Amazon, Occidental Northeast Atlantic and Paraná River basins) between 2013-2017. The digeneans found were rinsed in saline and fixed in $4 \%$ hot formalin or in molecular-grade $99 \%$ ethanol. Formalin-fixed specimens were transferred to $70 \%$ ethanol until further processing, i.e. staining and SEM studies. Host nomenclature and classification follows Froese and Pauly (2018).

\section{Morphological evaluation}

Specimens fixed in formalin were stained with Mayer's hydrochloric carmine solution, dehydrated in an ascending ethanol series, cleared with eugenol (clove oil) and mounted in Canada balsam as permanent preparations. Drawings were made using a drawing tube attached to an Olympus BX 51 microscope. Measurements were made using cellSens Dimension Software adapted to a dissecting microscope Olympus BX53 and are given in micrometres unless otherwise stated; metrical data are given as the range followed by the mean in parentheses.

Specimens for SEM observations were prepared using the methodology outlined by Kuchta and Caira (2010). Briefly, samples were hydrated in a graded ethanol series, dehydrated in a graded ethanol series, transferred to hexamethyldisilazane (HMDS) (Ted Pella, Inc., Redding, California), and allowed to air dry. They were subsequently mounted on aluminium stubs using double-sided carbon tape, sputter coated with 30-nm gold/ palladium, and examined with a JEOL JSM-7401F field emission scanning electron microscope (JEOL Ltd., Tokyo, Japan).

For comparison, the types and vouchers of cladorchiids deposited in the collection of the Instituto Nacional de Pesquisas do Amazonas, Manaus, Brazil (INPA), were studied (for list of specimens studied - see Pantoja et al. 2018). Some of the type and voucher specimens of cladorchiids collected by J. Natterer in the Brazilian Amazonia, then described by K.M. Diesing and deposited in the Natural History Museum in Vienna (Zoologisches Museum Wien - ZWM), were also studied. Holotypes and some paratypes of the taxa described here are deposited in the Helminthological Collection of the Instituto Oswaldo Cruz in Rio de Janeiro, Brazil (CHIOC), whereas other paratypes and vouchers are deposited in the Helminthological Collection of the Institute of Parasitology of the Biology Centre of the Czech Academy of Sciences, Czech Republic (IPCAS), Natural History Museum, Geneva, Switzerland (MHNG-PLAT), and Natural History Museum in London, UK (NHMUK).

\section{DNA isolation, amplification and sequencing}

Genomic DNA was isolated from single ethanol-fixed individuals by placing the samples in 200 microlitres (see Table 1 for a list of specimens sequenced) using Chelex ${ }^{\circledR}$ method containing $0.1 \mathrm{mg} / \mathrm{ml}$ proteinase $\mathrm{k}$, followed by incubation at $56^{\circ} \mathrm{C}$ for $3 \mathrm{~h}$, heating at $90^{\circ} \mathrm{C}$ for $8 \mathrm{~min}$, and centrifugation at $14,000 \mathrm{~g}$ for $10 \mathrm{~min}$. The internal transcribed spacer 2 (ITS2) was amplified using the primers GA1 [5-AGA ACA TCG ACA TCT TGA AC-3] (Anderson and Barker 1998) and BD2 [5-TAT GCT TAA ATT CAG CGG GT3] (Luton et al. 1992). PCR reactions (25 $\mu \mathrm{l})$ consisted of $2.5 \mu \mathrm{l}$ of $10 \times$ PCR buffer minus $\mathrm{Mg}, 1.5 \mu \mathrm{l}$ of $\mathrm{MgCl}_{2}$ $(50 \mathrm{mM}), 2 \mu \mathrm{l}$ of dNTP's $(2.5 \mathrm{mM}), 1.25 \mu \mathrm{l}$ of each oligonucleotide primer $(10 \mathrm{mM}), 0.2 \mu \mathrm{l}$ of Platinum Taq DNA polymerase

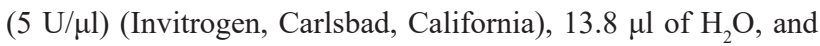
$2.5 \mu \mathrm{l}$ of genomic DNA. PCR cycling parameters for amplification were performed as described by Lotfy et al. (2010).

The 28S region of the rDNA was amplified using the primers digl2 (5-AAG CAT ATC ACT AAG CGG-3) and L0 [5-GCT ATC CTG AG (AG) GAAACT TCG-3] (Tkach et al. 2000). PCR reactions were made as described above and PCR cycling parameters for amplification were performed according to Tkach et al. (2000). The cytochrome c oxidase subunit 1 ( $\operatorname{cox} 1)$ region of the mtDNA was amplified using the primers JB3 [5-TTTTTTGGGCATCCTGAGGTTTAT-3] and JB4 [5-TAAAGAAAGAACATAAGTAAAATG-3] (Bowles et al. 1995). PCR reactions $(25 \mu \mathrm{l})$ consisted of $2.5 \mu \mathrm{l}$ of $10 \times$ PCR buffer minus $\mathrm{Mg}, 1.5 \mu \mathrm{l}$ of $\mathrm{MgCl}_{2}(50 \mathrm{mM}), 1.5 \mu \mathrm{l}$ of dNTP's $(2.5 \mathrm{mM}), 1.5 \mu \mathrm{l}$ of each oligonucleotide primer $(10 \mathrm{mM}), 0.25 \mu \mathrm{l}$ of Platinum Taq DNA polymerase $(5 \mathrm{U} / \mu \mathrm{l}), 14.25 \mu \mathrm{l}$ of $\mathrm{H}_{2} \mathrm{O}$, and $2 \mu \mathrm{l}$ of genomic DNA. PCR cycling parameters for amplification were as those used by Utuk and Piskin (2012).

PCR products were visualised with SYBR Green (Invitrogen, Eugene, Oregon) staining before electrophoresis on $1.5 \%$ agarose gels. The amplified products were purified with Exo-SAP-IT Kit (GE Healthcare Life Sciences, UK) following the manufacturer's instructions, sequenced using the same primers of PCR reactions and the ABI PRISM BigDye Terminator Cycle Sequencing Ready Reaction Kit (Applied Biosystems-Perkin Elmer, Waltham, 
Table 1. List of paramphistomoids whose sequences were used for analyses and sequences obtained in the present study from Brazil and Peru.

\begin{tabular}{|c|c|c|c|c|c|}
\hline Trematode species & Host species & 28S rDNA & ITS2 rDNA & $\operatorname{cox} 1 \mathrm{mtDNA}$ & Country \\
\hline Amurotrema dombrowskajae & Ctenopharyngodon idella & KT321869 & N/A & N/A & Russia \\
\hline Dadaytrema gracile & Pimelodella gracilis & MK604792 & $\mathrm{N} / \mathrm{A}$ & MN037796 & Brazil \\
\hline Dadaytrema gracile & Pimelodella megalura & MK604793 & MK604810 & MK907336 & Brazil \\
\hline Dadaytrema gracile & Pimelodus blochii & MK604827 & MK604818 & MK918487 & Brazil \\
\hline Dadaytrema gracile & Pimelodus fur & MK604789 & MK604813 & MK890103 & Brazil \\
\hline Dadaytrema minimum & Calophysus macropterus & $\mathrm{N} / \mathrm{A}$ & $\mathrm{N} / \mathrm{A}$ & MN037797 & Peru \\
\hline Dadaytrema minimum & Pimelodus sp. & MK604799 & MK604812 & MN037798 & Brazil \\
\hline Dadaytrema minimum & Ptrodoras granulosus & MK604791 & $\mathrm{N} / \mathrm{A}$ & $\mathrm{N} / \mathrm{A}$ & Peru \\
\hline Dadaytrema minimum & Pterodoras granulosus & N/A & N/A & MK890099 & Peru \\
\hline Dadaytrema minimum & Tocantinsia piresi & MK604800 & MK604829 & MK890100 & Brazil \\
\hline Dadaytrema minimum & Oxydoras niger & $\mathrm{N} / \mathrm{A}$ & MK604831 & N/A & Brazil \\
\hline Dadaytrema oxycephalum & Heros sp. & $\mathrm{N} / \mathrm{A}$ & $\mathrm{N} / \mathrm{A}$ & MK890101 & Brazil \\
\hline Dadaytrema oxycephalum & Myloplus schomburgkii & $\mathrm{N} / \mathrm{A}$ & $\mathrm{N} / \mathrm{A}$ & MN064561 & Brazil \\
\hline Dadaytrema oxycephalum & Pterodoras granulosus & MK604797 & MK604811 & MK907333 & Brazil \\
\hline Dadaytrema oxycephalum & Pterodoras granulosus & MK604790 & MK604833 & MN064562 & Brazil \\
\hline Dadaytrema oxycephalum & Pygocentrus nattereri & MK604795 & MK604817 & MK890102 & Brazil \\
\hline Dadaytrema oxycephalum & Tometes kranponhah & $\mathrm{N} / \mathrm{A}$ & N/A & MN068091 & Brazil \\
\hline Doradamphistoma bacuense & Megalodoras uranoscopus & MK604808 & $\mathrm{N} / \mathrm{A}$ & MN064563 & Brazil \\
\hline Doradamphistoma bacuense & Megalodoras uranoscopus & MK604803 & N/A & MN064564 & Peru \\
\hline Doradamphistoma bacuense & Megalodoras uranoscopus & $\mathrm{N} / \mathrm{A}$ & $\mathrm{N} / \mathrm{A}$ & MK907334 & Peru \\
\hline Doradamphistoma bacuense & Platydoras costatus & MK604806 & $\mathrm{N} / \mathrm{A}$ & MN068092 & Peru \\
\hline Doradamphistoma bacuense & Oxydoras niger & $\mathrm{N} / \mathrm{A}$ & MK604809 & MN099700 & Peru \\
\hline Doradamphistoma bacuense & Oxydoras niger & $\mathrm{N} / \mathrm{A}$ & N/A & MK907335 & Peru \\
\hline \multicolumn{2}{|c|}{ Doradamphistoma parauchenipteri $\mathrm{n}$. comb Brachyplatystoma vaillantii } & MK604828 & $\mathrm{N} / \mathrm{A}$ & $\mathrm{N} / \mathrm{A}$ & Brazil \\
\hline \multicolumn{2}{|c|}{ Doradamphistoma parauchenipteri $\mathrm{n}$. comb Trachelyopterus galeatus } & MK604807 & MK604834 & MK800104 & Brazil \\
\hline \multicolumn{2}{|c|}{ Doradamphistoma parauchenipteri $\mathrm{n}$. comb Trachelyopterus galeatus } & MK604830 & $\mathrm{N} / \mathrm{A}$ & N/A & Peru \\
\hline \multicolumn{2}{|c|}{ Doradamphistoma parauchenipteri $\mathrm{n}$. comb.Trachelyopterus galeatus } & $\mathrm{N} / \mathrm{A}$ & $\mathrm{N} / \mathrm{A}$ & MN099701 & Brazil \\
\hline Goeldamphistomum peruanum & Duopalatinus peruanum & MK604832 & $\mathrm{N} / \mathrm{A}$ & N/A & Peru \\
\hline Helostomatis cf. helostomatis & Labiobarbus siamensis & MK604798 & N/A & N/A & Thailand \\
\hline Iquitostrema papillatum & Hassar orestis & MK604819 & $\mathrm{N} / \mathrm{A}$ & MN104942 & Peru \\
\hline Pisciamphistoma stunkarkdi & Lepomis megalotis & MK604794 & $\mathrm{N} / \mathrm{A}$ & $\mathrm{N} / \mathrm{A}$ & USA \\
\hline Pseudocladorchis nephrodorchis & Myloplus rubripinnis & MK604801 & $\mathrm{N} / \mathrm{A}$ & N/A & Brazil \\
\hline Pseudocladorchis nephrodorchis & Serrasalmus manuelli & MK604804 & N/A & N/A & Brazil \\
\hline Pseudocladorchis nephrodorchis & Tometes kramponhah & MK604805 & $\mathrm{N} / \mathrm{A}$ & N/A & Brazil \\
\hline Pseudocladorchis romani $\mathrm{sp} . \mathrm{n}$. & Oxydoras niger & MK604796 & $\mathrm{N} / \mathrm{A}$ & $\mathrm{N} / \mathrm{A}$ & Peru \\
\hline Pseudocladorchis romani $\mathrm{sp} . \mathrm{n}$. & Pterodoras granulosus & MK604816 & $\mathrm{N} / \mathrm{A}$ & MN099702 & Peru \\
\hline Pseudocladorchis romani $\mathrm{sp} . \mathrm{n}$. & Pterodoras granulosus & $\mathrm{N} / \mathrm{A}$ & $\mathrm{N} / \mathrm{A}$ & MN177615 & Peru \\
\hline Diplodiscus subclavatus & $\begin{array}{l}\text { Pelophylax ridibundus } \\
\text { (formerly Rana ridibunda) }\end{array}$ & AY222212 & N/A & N/A & Bulgaria \\
\hline Calicophoron microbothrium & Bulinus forskalii & N/A & GU735639 & N/A & Tanzania \\
\hline Cladorchiidae gen. sp. & Metynnis lippincottianus & MK604802 & $\mathrm{N} / \mathrm{A}$ & MN099703 & Brazil \\
\hline Cladorchiidae gen. sp. & Myleus setiger & $\mathrm{N} / \mathrm{A}$ & $\mathrm{N} / \mathrm{A}$ & MN099704 & Brazil \\
\hline Cladorchiidae gen. sp. & Tetranematichthys quadrifilis & MK604815 & N/A & MK907332 & Brazil \\
\hline
\end{tabular}

Massachusetts) in a MegaBACE sequencer (GE Healthcare Life Sciences). Contiguous sequences were assembled in Geneious (Geneious ver. 9 created by Biomatters, available from http://www.geneious.com/) and deposited in GenBank.

\section{Phylogenetic analyses}

Sequences obtained in this study and those retrieved from GenBank (Table 1) were aligned using the E-INS-I algorithm of the program MAFFT (Katoh and Standley 2013) implemented in Geneious, excluding ambiguously aligned positions. Alignments were analysed using Bayesian inference (BI) and maximum likelihood (ML) methods employing the nucleotide substitution model which was calculated in the program jModelTest v2.1.10 (Darriba et al. 2012). For 28S rDNA analysis, the nucleotide substitution model was GTR + I + G. For cox 1 mtDNA analysis, the nucleotide substitution model was GTR $+\mathrm{G}$ and for ITS2 analysis, the nucleotide substitution model was $\mathrm{K} 80+\mathrm{G}$. The best ML esti- mate was obtained from 100 searches in the program GARLI ver. 2.01 (Zwickl 2006) using default settings. The nodal support was evaluated by running tree searches on each of the 500 bootstrap replicates in GARLI. A BI tree was constructed using MrBayes ver. 3.2 (Ronquist et al. 2012) running two independent MC3 runs of 4 chains (one cold, three heated) for 5 million generations (ngen $=5,000,000$ ), sampling tree topologies every 1,000 th generation (samplefreq $=1,000$ ) and the first 500 samples were discarded as burn-in (burninfrac $=0.10)$. Tracer v.1.6 (Rambaut et al. 2014) was used to check the convergence and mixing of different parameters and to confirm that the effective sample size (ESS) of each parameter was adequate to provide reasonable estimates of the variance in model parameters (i.e. ESS values >200).

The diplodiscid Diplodiscus subclavatus (Pallas, 1760) (AY222212) was used as outgroup for 28S rDNA analysis. Sequences of the cladorchiid Amurotrema dombrowskajae Achmerov, 1959 (KT321869) obtained from GenBank and newly gener- 
ated sequences of the cladorchiids Helostomatis cf. helostomatis (MacCallum, 1905) from Thailand and Pisciamphistoma stunkardi (Holl, 1929) from USA were added to the analysis. Diplodiscus mehrai Pande, 1937 (GU735639) was used as outgroup for ITS2 rDNA analysis. An unrooted tree was generated for cox 1 mtDNA data because of long branches in the outgroup.

\section{RESULTS}

Morphological evaluation of numerous specimens of cladorchiid digeneans found in freshwater fishes in Brazil and Peru from 2004 to 2018 has revealed the presence of 14 species, in addition to the three new species recently described by Pantoja et al. (2018). Out of these 14 species, three are new to science and are described in the present paper. A list of previously known species is provided and SEM micrographs of seven species are presented. In addition, sequences of 28S rDNA of 27 isolates of 13 species, sequences of ITS2 rDNA of 11 isolates of five species and sequences of cox $1 \mathrm{mtDNA}$ of 28 isolates of 10 species were obtained. A total of 1.073, 365 and 396 characters were observed after complete alignment of the $28 \mathrm{~S}$ rDNA, ITS2 rDNA and cox1 mtDNA, respectively.

\section{Cladorchiidae in freshwater fishes from Brazil and Peru}

Species and subfamilies are listed alphabetically, with the new taxa listed first. New host records are indicated by an asterisk $(*)$.

Superfamily Paramphistomoidea Fischoeder, 1901

Family Cladorchiidae Fischoeder, 1901

Subfamily Dadayiinae Fukui, 1929

\section{Microrchis macrovarium $\mathrm{sp} . \mathrm{n}$.}

Fig. 1A; Table 2

ZooBank number for species:

urn:1sid:zoobank.org:act:14F7648A-7B66-4E79-850E-384ED87BE8F6

Material studied: one specimen from Pimelodella cristata (Müller et Troschel) (PAIA 49) and one from Tetranematichthys quadrifilis (Kner, 1858) (PAIA 01 - IPCAS D-790/2), Maracanã River in Igarapé-açu, Pará, Brazil, 15.vii.2016, collected by A. Pereira and C. Pantoja; one from $P$. cristata (PI 183 - IPCAS D-790/1) and three from Pterodoras granulosus (Valenciennes) (PI 1000, 1001), Iquitos, Loreto, Peru, 13.iv.2005 and 19.iv.2018, T. Scholz and R. Kuchta; all mounted as permanent preparations.

Description (based on five specimens; measurements of specimens from different hosts are in Table 2): body elongate, with maximum width in mid-body. Acetabulum with posteromedial notch. Anterior extremity tapered. Domeshaped tegumentary papillae around oral opening, extending to level of pharynx. Pharynx with anterior sphincter only and paired primary intramural sacs. Oesophagus sinuous, with moderately-developed muscle fibres throughout. Slender elongate oesophageal bulb present, often laterally tilted. Caeca only slightly sinuous; extremities do not approach close to acetabulum.
Testes intercaecal, directly tandem, not contiguous, subspherical to transversely oval. Cirrus-sac immediately postbifurcal, oval, contains internal seminal vesicle and prostatic cells distally. Genital pore immediately postbifurcal, surrounded by glandular tissue.

Ovary median, between caecal ends, ovoid, as large as or usually larger than testes. Laurer's canal not seen. Vitelline follicles in lateral fields from level of posterior testis to about that of ovary. Uterus in small specimens forms descending limb which encroaches laterally to level of caecal ends; ascending limb mainly intercaecal, filling intercaecal and intertesticular space; in larger specimens, descending and ascending limbs tend to encroach across caeca. Eggs numerous. Excretory vesicle and duct not seen.

Ty pe host: Pimelodella cristata (Siluriformes: Heptapteridae). Additional hosts: Tetranematichthys quadrifilis (Siluriformes: Auchenipteridae); Pterodoras granulosus (Siluriformes: Doradidae).

Type 1 o c a lity: Marapanim River, Igarapé-açu, Pará, Brazil $\left(01^{\circ} 07^{\prime} 44^{\prime \prime} \mathrm{S} ; 47^{\circ} 37^{\prime} 12^{\prime \prime} \mathrm{W}\right)$.

Additional loc ality: Iquitos, Loreto Region, Peru (Am-

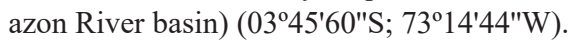

Site of infection: intestine.

Infection rate: Pimelodella cristata (Brazil): infected one of two fish examined with 1 trematode, i.e. $1 / 2$ (1); P. cristata (Peru): 1/2 (1); Pterodoras granulosus (Peru): 1/32 (2); T. quadrifilis (Brazil): 1/2 (3).

Type materia 1: holotype (specimen from fish PAIA049a - CHIOC 40056); three paratypes (CHIOC 40057); two paratypes (IPCAS D-790/1, 2).

Representative DNA sequences: not available.

E t y m olog y: species name reflects the large size of the ovary relative to the testes: macro - large, ovarium - ovary.

Differential diagnosis. The new species is placed in Microrchis based on the combination of the pharynx with intramural sacs and an anterior sphincter, characteristic of the microrchis type of Näsmark (1937), an oesophageal bulb is present, the caecal ends do not approach the acetabulum, the testes are entire and subspherical, the genital pore is closely postbifurcal, the uterus forms extensive descending coils, the vitelline fields fail to extend anterior to the anterior testis or to reach the caecal ends. All four species of Microrchis (see below for the list of nominal species of the genus) have a posteromedial notch in the posterior rim of the acetabulum.

The genus was erected by Daday (1907) to accommodate Microrchis megacotyle (Diesing, 1836) (syn. Amphistoma megacotyle Diesing, 1836; type species) and $M$. ferrumequinum (Diesing, 1836) (syn. A. ferrumequinum Diesing, 1836) (Daday 1907). The third species, Microrchis oligovitellum Lunaschi, 1987, was described from Luciopimelodus pati (Valenciennes) and Trachycorystes striatulus (Steindachner) in Argentina by Lunaschi (1987).

The new species differs from all three in that the testes are directly tandem, not oblique, and that the ovary, between the caecal ends, is widely separated from the testes. It differs further from $M$. megacotyle and M. ferrumequinum in that the ovary is larger than the testes, a character it 


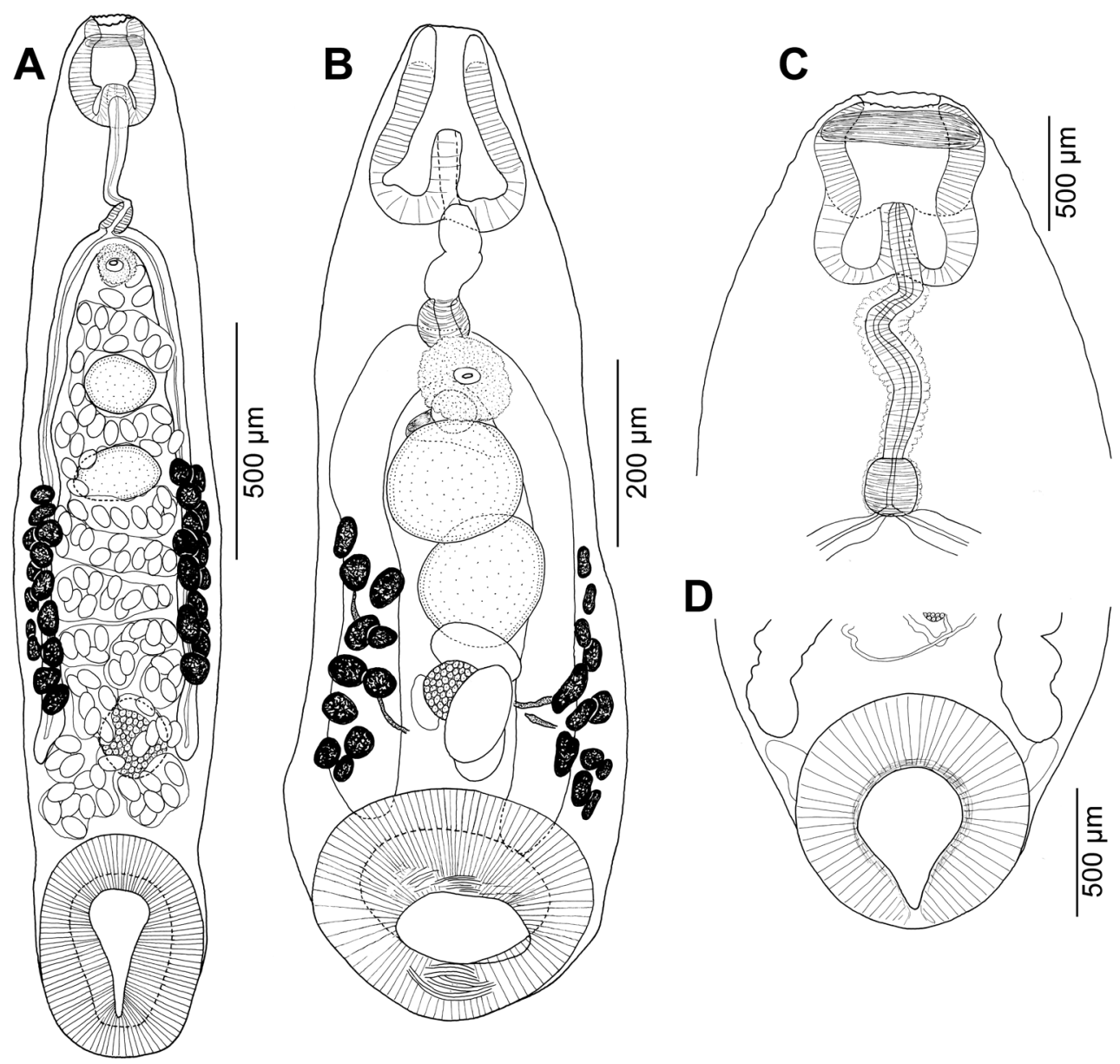

Fig. 1. A - Microrchis macrovarium sp. n. from Pimelodella cristata (Müller et Troschel), Brazil; ventral view of holotype (CHIOC 40056); B - Pronamphistoma philippei sp. n. from Heros sp., Brazil; ventral view of holotype (CHIOC 40058a); C, D - Doradamphistoma bacuense Thatcher, 1999 from Megalodoras uranoscopus (Eigenmann et Eigenmann), Brazil; anterior extremity (C) and acetabulum (D) of paratype (INPA 372c).

Table 2. Measurements of Microrchis macrovarium sp. n. from different hosts (in micrometres unless otherwise state).

\begin{tabular}{|c|c|c|c|}
\hline Host & Pimelodella cristata (type host) & Pterorodoras granulosus & Tetranematichthys quadrifilis \\
\hline Country (Coll. No.*) & $\begin{array}{l}\text { Brazil (CHIOC 40056), } \\
\text { Peru (IPCAS D-790/1) }\end{array}$ & CHIOC 40057 & Brazil (IPCAS D-790/2) \\
\hline Number of specimens & 2 & 1 & 1 \\
\hline Total length (mm) & $2.16-2.32$ & 1.58 & 1.20 \\
\hline Maximum width & $436-605$ & 389 & 215 \\
\hline Acetabulum length & $461-471$ & 299 & 300 \\
\hline Acetabulum width & $347-379$ & 300 & 230 \\
\hline Pharynx length & 172-191 & 86 & 114 \\
\hline Pharynx width & $145-152$ & 94 & 106 \\
\hline Pharyngeal sac (right) & 32 & 38 & 22 \\
\hline Pharyngeal sac (left) & $32-35$ & 40 & 20 \\
\hline Oesophagus length & $232-374$ & 411 & 210 \\
\hline Oesophageal bulb length & $63-73$ & 97 & 68 \\
\hline Caecal bifurcation to anterior extremity & $458-475$ & 420 & 265 \\
\hline Caecum (right) (mm) & $1.05-1.17$ & 0.88 & 0.56 \\
\hline Caecum (left) (mm) & $1.15-1.19$ & 0.97 & 0.59 \\
\hline Anterior testis length & 103-107 & 126 & 39 \\
\hline Anterior testis width & $96-136$ & 126 & 35 \\
\hline Posterior testis length & $99-120$ & 110 & 52 \\
\hline Posterior testis width & $128-177$ & 96 & 40 \\
\hline Ovary length & $165-186$ & 92 & 85 \\
\hline Ovary width & $165-186$ & 96 & 74 \\
\hline Egg & collapsed & collapsed & collapsed \\
\hline
\end{tabular}

* CHIOC - Helminthological Collection of the Instituto Oswaldo Cruz in Rio de Janeiro, Brazil; IPCAS - Helminthological Collection of the Institute of Parasitology of the Biology Centre of the Czech Academy of Sciences, České Budějovice, Czech Republic 
shares only with $M$. oligovitellum, which is, however, the only species described with a bifurcal rather than a closely postbifurcal genital pore, vitelline follicles restricted to two very short lateral fields overlying the caeca just posterior to the level of the ovary, and uterine coils extending across the caeca throughout their length.

In $M$. megacotyle, the uterus is entirely intercaecal and in M. ferrumequinum it extends just beyond the level of the caecal ends but is otherwise intercaecal. The new species further differs from both in having rather more restricted vitelline fields, which do not extend anterior to the level of the posterior testis. These specimens are therefore considered to be new and are named M. macrovarium.

Remarks. The new species occurs in fishes of two different families of catfishes from two river basins of South America, i.e. the Amazon and Marapanim Rivers. Yamaguti (1958) erected the subfamily Microrchiinae for $\mathrm{Mi}$ crorchis Daday, 1907 and Travassosinia Vaz, 1932. Recognised by Sey $(1988,1991)$, the subfamily was subsequently synonymised with the Dadayiinae Fukui, 1929 by Jones (2005b).

\section{Pronamphistoma philippei sp. $\mathrm{n}$.}

Fig. 1B

ZooBank number for species:

urn:1sid:zoobank.org:act:1810CFBD-D47A-41B9-825D-1D9C36043F20

Material studied: six mounted specimens from Heros sp. (PAIA 99), Marapanim River in Igarapé-açu, Pará, Brazil, 15.vii.2016, A. Pereira and C. Pantoja.

Description (based on six specimens, four gravid): body tiny, 814-1,035 (947; $\mathrm{n}=6$ ) long, tapered anteriorly, with maximum width $277-347(310 ; \mathrm{n}=4)$ in pre-acetabular region. Acetabulum almost as wide as body, 185-243 long and 262-307 wide; arc-like concentrations of strongly-developed ventral exterior circular and dorsal exterior circular muscle fibres visible in and arching across mid-line in anterior and posterior regions of acetabulum.

Oral opening terminal. Pharynx 83-100 long and 57-71 wide, with paired primary extramural pharyngeal sacs, right 56-83 long, left 57-79 long, each slightly more voluminous than pharynx. Oesophagus medium in length, 83164 long, flexed. Oesophageal bulb present, 52-59 long. Muscle fibres clearly visible in oesophagus and bulb; both delicate but well developed. Caeca fairly straight, wide, ends usually overlap anterior rim of acetabulum or may just fail to reach it; right caecum 420-562 long, left caecum 410-595 long.

Testes in middle third of body, intercaecal, rounded, entire, usually very slightly obliquely tandem, contiguous, anterior testis 95-215 long and 98-249 wide, posterior testis 116-214 long and 116-268 wide. Cirrus-sac present, rounded, contains internal seminal vesicle. Genital pore immediately postbifurcal, median, surrounded by glandular tissue.

Ovary rounded, 41-93 long and 50-56 wide, median or just submedian, slightly anterior to level of caecal ends and removed from acetabulum, just contiguous with posterior testis or not. Mehlis' gland complex appears to be posterodorsal to ovary. Laurer's canal not seen. Vitelline follicles in lateral fields along caeca from approximately intertesticular level almost to caecal ends; follicles encroach towards mid-line at level of ovarian complex, becoming confluent. Uterine walls difficult to see; gravid specimens contain 2-9 large eggs at level of ovary and posterior testis. Excretory vesicle and excretory pore not seen.

Type and only known host: Heros sp. (Perciformes, Cichlidae).

Ty pe 1 o c a lity: Marapanim River, Igarapé-açu, Pará, Brazil $\left(01^{\circ} 07^{\prime} 44^{\prime \prime} \mathrm{S} ; 47^{\circ} 37^{\prime} 12^{\prime \prime} \mathrm{W}\right)$.

Type material: holotype (specimen from host PAIA 99a - CHIOC 40058a), 2 paratypes (CHIOC 40058b,c); two paratypes (IPCAS D-791/1).

Z o o B a n k registratio n : urn:lsid:zoobank.org:act:1810CFBDD47A-41B9-825D-1D9C36043F20

Site of infection: intestine.

Infection rate: 1/5 (8).

Representative DNA sequences: not available.

E ty m o log y: the species is named after Philippe Vieira Alves, Brazil, for his help during sampling trips in Brazil and advice in analysing molecular data.

Differential diagnosis. The new species is placed in Pronamphistoma Thatcher, 1992, which was erected for the type and, until now, the only species $P$. cichlasomae Thatcher, 1992, described by Thatcher (1992) from Heros severus Heckel in Brazil (Rondonia). Closely though the present specimens resemble $P$. cichlasomae, they differ significantly from this species, whose holotype and paratypes (INPA 454 and $455 \mathrm{a}-\mathrm{j}$ ) were studied by the authors. The similarities include the small body size, intercaecal testes (figured as slightly obliquely tandem by Thatcher 1992), postbifurcal genital pore, ovary close to the posterior testis and the small number of relatively large eggs.

The differences are the absence of the anterior collar-like expansion described in the type-species, the presence of extramural rather than intramural pharyngeal sacs, and the unusual development of the dorsal exterior circular and ventral exterior circular muscle fibre series in the acetabulum of the new species. Furthermore, the fan-like configuration of the vitelline gland described by Thatcher (1992) was not observed in the present specimens, in which the follicles extend along the caeca in lateral fields, with some encroaching towards the midline at the level of the ovarian complex to become broadly confluent.

The anterior collar-like expansion described by Thatcher (1992) is visible in some but not all specimens of the type-series of $P$. cichlasomae, but seems to be a genuine feature consistently present in most. Collar- or shoulder-like expansions near the anterior extremity in several cladorchiids have been treated at generic level by various authors and seem to be a consistent feature in the taxa where it has been described. This feature has not been seen in our specimens.

Thatcher (1992) described and figured the pharyngeal sacs in $P$. cichlasomae as intramural but they are clearly extramural in our specimens. He described the oesophagus as short but it may have been flexed and partly concealed by the pharynx. The development of the dorsal and ventral 
circular muscle units observed in the acetabulum of our specimens was not mentioned by Thatcher (1992) but may not have been observed or considered by him. In comparing our specimens with the type series of $P$. cichlasomae, we are aware that the less than optimal condition of those types renders it difficult to make comparisons as fully as we would wish. Nevertheless, we consider that the differential characters presented above justify species status for the present specimens, under the name of P. philippei n. sp.

Remarks. Because of the addition of another species to the previously monotypic genus, the generic diagnosis of Pronamphistoma is amended as presented below.

\section{Pronamphistoma Thatcher, 1992}

Amended generic diagnosis: body small, tapered anteriorly; maximum width in pre-acetabular region. Anterior collar-like expansion present or absent. Acetabulum without posteromedial notch in posterior rim; dorsal and ventral exterior circular muscle series well developed in mid-line or not. Oral opening terminal. Pharynx with intraor extramural paired primary pharyngeal sacs. Oesophageal bulb present. Caeca wide, reaching acetabulum or not. Testes ovoid, entire, intercaecal in middle third of body, contiguous, obliquely tandem. Cirrus-sac ovoid, contains internal seminal vesicle. Genital pore closely postbifurcal, surrounded by glandular tissue. Ovary rounded or spherical, median or submedian, just anterior to caecal ends, contiguous with posterior testis or not. Laurer's canal not seen. Mehlis' gland complex posterodorsal to ovary. Uterus contains few large eggs. Vitelline follicles in lateral fields along caeca from intertesticular level almost to caecal ends, broadly confluent at level of ovary, or form fanlike configuration on each side. Excretory vesicle saccate. In intestine of cichlid fishes (Heros spp.), Brazil.

\section{Dadayius marenzelleri (Daday, 1907) Fukui, 1929}

Syns Amphistoma oxycephalum of Diesing (1836)

(partim); Diplodiscus marenzelleri Daday, 1907

Material studied: type material (see below); three specimens from Trachelyopterus galeatus (Linnaeus) (PA 146 - IPCAS D-792/1), Marapanim River, Igarapé-açu, Pará, Brazil, 31.vii.2016, C. Pantoja.

Type host: 'Salmo sp.' (in fact a characiform fish, most probably a serrasalmid).

Type locality: not explicitly mentioned, either Cuiabá (state of Mato Grosso), or the Paraná River, Brazil.

Type material: specimens on slides 980 and 984 of Diesing's (1836) collection at the Natural History Museum, Vienna (ZMW).

Additional hosts: Mylossoma aureum (Spix et Agassiz) (Characiformes: Serrasalmidae); ${ }^{*} T$. galeatus (Linnaeus) (Siluriformes: Auchenipteridae).

Site in host: intestine.

Infection rate: T. galeatus: $1 / 27$ (5).

D is tribution: Brazil (type locality - not specified; Marapanim River, Igarapé-açu, Pará, Brazil - new locality).

Representative DNA sequences: not available.
Remarks. The species was described as D. marenzelleri by Daday (1907) who found a mixture of species on two of Diesing's (1836) slides from 'Salmo sp.' He differentiated his new species from the only congener from fish, Diplodiscus cornu (Diesing), by the presence of a 'genital sucker' (absent in D. cornu). The present specimens correspond in their morphology including the total size of the body and the relative size of the pharynx and 'genital sucker'. In fact, there is no true genital sucker in this taxon nor in Dadayius pacuensis (see below). The area surrounding the genital pore is slightly elevated and glandular but lacks a sucker-like structure.

Dadayius pacuensis Thatcher, Sey et Jégu, 1996

Fig. $2 \mathrm{~A}-\mathrm{C}$

Material studied: type material (see below); 50 specimens from Metynnis lippincottianus (Cope), Marapanim River, Igarapé-açu (PAIA 06f, 13b, 70c, 72a, 95a, 102c, 105a, 108c, 110a,), Pará, Brazil, 19.vii.2016, C. Pantoja; five from M. lippincottianus (PI 190a), Iquitos, Loreto Province, Peru, 16.iv.2005, T. Scholz and R. Kuchta (IPCAS D-793/1).

Type host: Myloplus rubripinnis (Müller et Troschel) (Characiformes: Serrasalmidae).

Type locality: Jatapu River, Amazonas, Brazil.

Ty pe materia 1 : holotype INPA 203; paratypes INPA 203a-e.

Additional hosts: Metynnis hypsauchen (Müller et Troschel), *M. lippincottianus, Myloplus asterias (Müller et Troschel), Myloplus sp. (Characiformes: Serrasalmidae).

Site of infection: intestine.

Infection rate: Metynnis lippincottianus (Brazil): 12/16 (38; maximum 81 specimens); M. lippincottianus (Peru): 1/1 (16).

D i s t r i b u t i o n : Brazil (Marapanim River, Igarapé-açu, Pará new locality); Peru (Iquitos, Loreto - new locality).

Representative DNA sequences: not available.

Remarks. New material from the serrasalmid M. lippincottianus corresponds to D. pacuensis, confirmed by a study of its holotype (INPA 203) and paratypes (INPA 203b, e). Dadayius pacuensis was described from M. rubripinnis by Thatcher et al. (1996) and differentiated from the type and only species, $D$. marenzelleri, by its massive acetabulum, relatively larger pharynx and genital sucker, and smaller body size (half the size of the type species Thatcher et al. 1996). It has a massive acetabulum with incomplete transverse ridges on the luminal surface. Both $D$. marenzelleri and D. pacuensis were described with these ridges, which Thatcher et al. (1996) regarded as a generic character. Dadayius marenzelleri was illustrated by Thatcher et al. (1996) with directly tandem testes. The size of our specimens from $M$. lippincottianus is consistent with this species but, according to Thatcher et al.'s (1996) generic diagnosis, it has a genital sucker and lacks a cirrus-sac. A thin-walled cirrus-sac has been noted in the present specimens and the testes are obliquely tandem.

However, two other species of Dadayius, D. pacupeva Lacerda, Takemoto et Pavanelli, 2003 and D. puruensis Lopes, Karling, Takemoto, Rossoni, Ferreira et Pavanelli, 

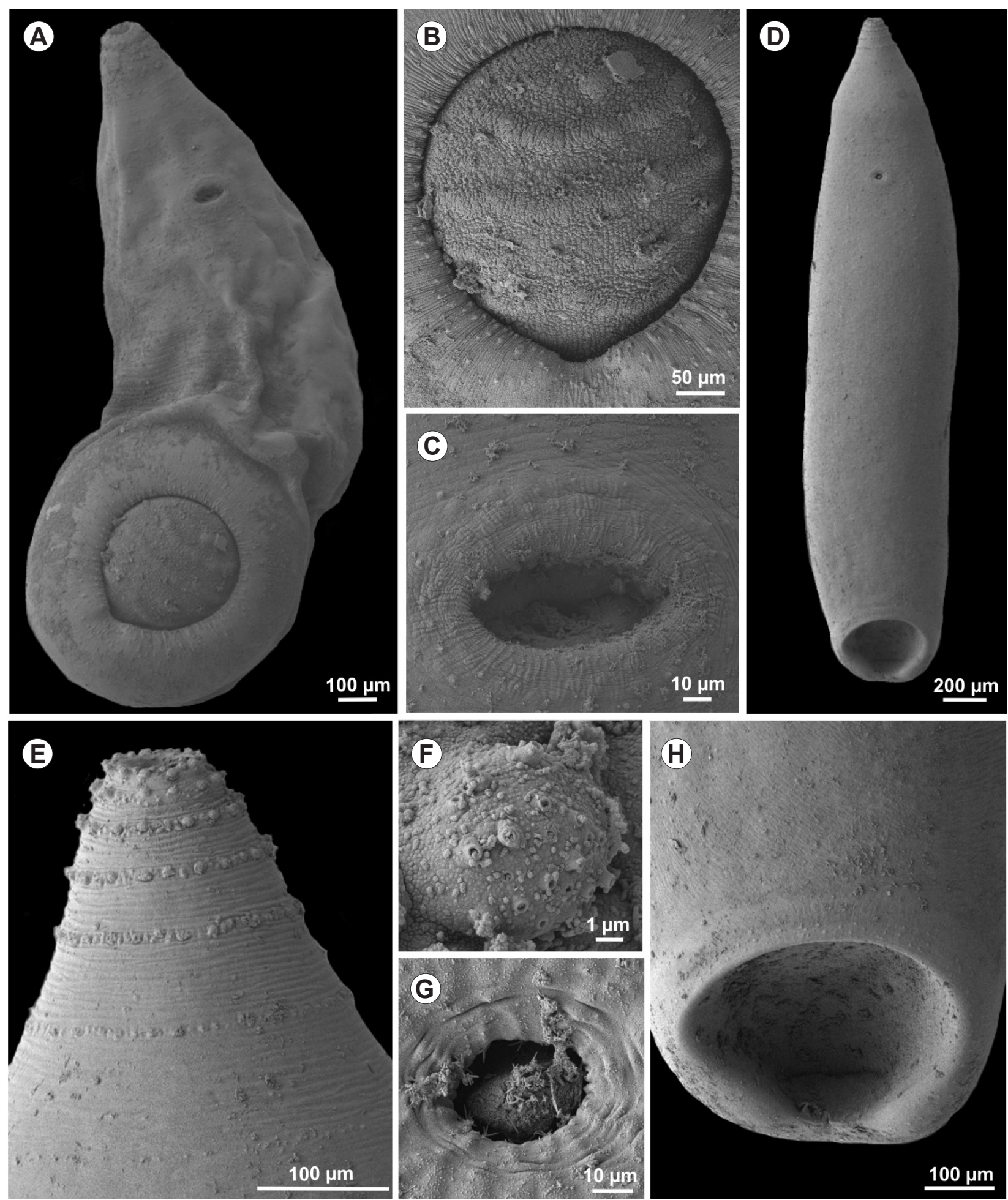

Fig. 2. A-C - Dadayius pacuensis Thatcher, Sey et Jégu, 1996 from Metynnis lippincottianus (Cope), Brazil. A - ventral view; B - acetabulum with transverse ridges on the luminal surface; $\mathrm{C}$ - genital pore showing the absence of a genital sucker. D-H - Dadaytrema gracile Lunaschi, 1989 from Pimelodella gracilis (Valenciennes), Brazil. D - ventral view; E - anterior extremity showing distribution of papillae; F - single multiciliate papilla on the anterior extremity; $\mathrm{G}$ - genital pore; $\mathrm{H}$ - acetabulum.

2011, were described as lacking visible transverse ridges (Lacerda et al. 2003, Lopes et al. 2011).

Our specimens resemble $D$. pacupeva in having obliquely tandem testes (described as tandem in D. pacupeva but figured as obliquely tandem) and the ovary between the caecal ends, but differ in the greater size of the acetabulum relative to the body and the presence of transverse ridges on its luminal surface, confirmed in the present study (Fig. 2B). The caeca reach or almost reach the acetabulum, a cirrus-sac is present and a true genital sucker is absent. The area around the genital pore is slightly elevated and glandular but lacks a sucker as defined by Näsmark (1937) 
and Eduardo (1982). Their interpretation is followed here. These specimens therefore cannot be allocated to $D$. pacupeva.

Our specimens cannot be $D$. puruensis, which differs in apparently lacking transverse ridges in the lumen of the acetabulum and a posteromedial acetabular notch. Also, this species is said to have a genital sucker, vitelline follicles anterior to the caecal arch and an arc-shaped ovary. The position of the vitelline follicles, if confirmed, would be highly unusual for the superfamily and requires reassessment. A cirrus-sac was considered absent or not observed and the uterus and eggs were not observed. This suggests that these specimens were immature. These specimens are closest to D. pacuensis, but the genus requires revision and re-examination of all type-series to clarify interpretation of the terminal genitalium and ascertain whether the reported absence of a cirrus-sac and of transverse ridges in some taxa results from the difficulty of observing them.

Scanning electron microscopy has revealed the presence of concentric rings of dome-shaped, non-ciliate tegumentary papillae around the anterior extremity, on the rim of the acetabulum and around the genital pore (Fig. 2A-C).

\section{Dadaytrema gracile Lunaschi, 1989}

Fig. 2D-H

Material studied: five specimens from Pimelodella gracilis (Valenciennes) (BR-MS 99 - IPCAS D-794/1); three from Pimelodella megalura Miranda Ribeiro (BR-MS 40, 41, 66 - IPCAS D-794/2); five from Pimelodus fur (Lütken) (BRMS 42, 47, 48, 58, 112 - IPCAS D-794/4), all Miranda River, Pantanal, Mato Grosso do Sul, Brazil, 22.x.2015, C. Pantoja and T. Scholz; three from Pimelodus blochii Valenciennes (BR-RO 61, 62), Quatro Cachoeiras River, Ariquemes, Rondônia, Brazil, 9.x.2015, T. Scholz (IPCAS D-794/3).

Type host: Pimelodella gracilis (Siluriformes: Heptapteridae).

Type locality: Arroyo Brazo Chico, Uruguay River basin, Entre Ríos Province, Argentina.

Type material: type specimens (six adult and seven immature worms, all flattened) in the Colección Helmintológica, Museo de La Plata, Argentina (Coll. Nos. 1289C-1306C).

Additional hosts: *P. megalura (Siluriformes: Heptapteridae); *P. blochii, *P. fur (Siluriformes: Pimelodidae).

Site of infection: intestine.

Infection rate: Pimelodella gracilis: 1/1 (14); P. megalura: 3/3 (3); P. blochii: 2/8 (3); P. fur: 5/13 (7).

D istribution: Argentina, Brazil (Miranda River, Pantanal, Mato Grosso do Sul, 20¹1'27"S; 56²30'19"W; Quatro Cachoeiras River, Ariquemes, Rondônia, $10^{\circ} 01^{\prime} \mathrm{S}$; $63^{\circ} 03^{\prime} \mathrm{W}$; both new localities).

Representative DNA sequences: see Table 1 and Figs. 6-8.

Remarks. The species was described by Lunaschi (1989) from the heptapterid catfish P. gracilis from Entre Ríos Province in Argentina (Paraná River basin). It was differentiated from $D$. oxycephalum by the diagonal, not tandem position of the testes, which are almost entire, and by the extracaecal position of the uterus (versus almost exclusively intercaecal in $D$. oxycephalum). New material collected from the same river basin as the type locality and from the Amazon River basin extends the distribution of the species and the spectrum of its definitive hosts to inc- lude another species of Pimelodella, P. megalura, and two pimelodid catfishes, $P$. blochii and $P$. fur.

For the first time, the species was studied using SEM and details of the tegumentary papillae, which were not reported in the original description, are provided here. The papillae are arranged in several concentric circles around the anterior extremity (Fig. 2E) and are bluntly dome-shaped and multiciliate (Fig. 2F). The acetabular rim also appears to bear small, dome-shaped, non-ciliate papillae (Fig. 2H).

Since the latin suffix -trema is neuter, not feminine, the species name is amended to gracile.

\section{Dadaytrema minimum Vaz, 1932}

Fig. 3A-D

Material studied: one specimen from Calophysus macropterus (Lichtenstein, 1819) (PI 101) and ten from P. granulosus (PI 350, 441, 758b, 829, 981, 982, 1000, 1001), Iquitos, Peru, 9.ix.2006, 3.iii.2011, 15.iv.2018 (IPCAS D-795/2), T. Scholz, R. Kuchta; five from Pimelodus sp. (TO 23c), Araguaia River at Santa Isabel, Pará, Brazil, 23.x.2014; five from Tocantinsia piresi (Miranda-Ribeiro) (BR-X 58a), Xingu River in Altamira, Pará, Brazil, 24.iv.2013 (IPCAS D-795/1), T. Scholz.

Type host: Myleus sp. (= Myloplus sp.) ('pacú branco') (Characiformes: Serrasalmidae).

Type locality: Rio Paranapanema, São Paulo, Brazil.

Type materia 1: holotype and paratypes in the Colección Helmintológica, Instituto Biológico de São Paulo, Brazil (No. 461).

Additional hosts: *Calophysus macropterus, *Pimelodus sp. (Siluriformes: Pimelodidae); *P. granulosus (Siluriformes: Doradidae); ${ }^{*}$ T. piresi (Siluriformes: Auchenipteridae).

Site of infection: intestine.

In fection rate: C. macropterus (Peru): 1/35 (1); Pimelodus sp. (Brazil): 1/1 (5); P. granulosus: 21/32 (3; maximum 15); T. piresi: $1 / 2(5)$.

D istribution: Brazil (Rio Paranapanema, São Paulo; Araguaia River, Santa Isabel, Pará, 0605'23"S; 48¹6'46"W; Xingu River, Altamira, Pará, $3^{\circ} 35^{\prime} 45^{\prime \prime S}$; 51 $49^{\prime} 01^{\prime \prime} \mathrm{W}$ - both

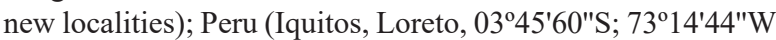
- new locality).

Representative DNA sequences: see Table 1 and Figs. 6-8.

Remarks. The species was described as D. minima (the generic name is neuter and thus the ending of the species name should be -um) from the serrasalmid Myleus sp. (= Myloplus sp.) by Vaz (1932). He did not differentiate it from $D$. elongatum and $D$. oxycephalum, just mentioned its small size (total length of 2.0-2.5 mm; maximum width of $1.3-1.5 \mathrm{~mm}$ ) and a very short oesophagus. Based on Vaz's (1932) figures, it is also possible to distinguish this species from $D$. elongatum and $D$. oxycephalum by the widely oval shape of the body steadily narrowing towards the anterior extremity (versus more oblong in the latter species; compare figs. 14-17 with figs. 5-7 and 10-14 in Vaz 1932). Even though Heyneman et al. (1960) and Vicente et al. (1978) synonymised all three species, they did not provide convincing arguments for this synonymy. In addition, molecular data unequivocally establish the existence of at least three separate species of Dadaytrema (see Fig. 6). 

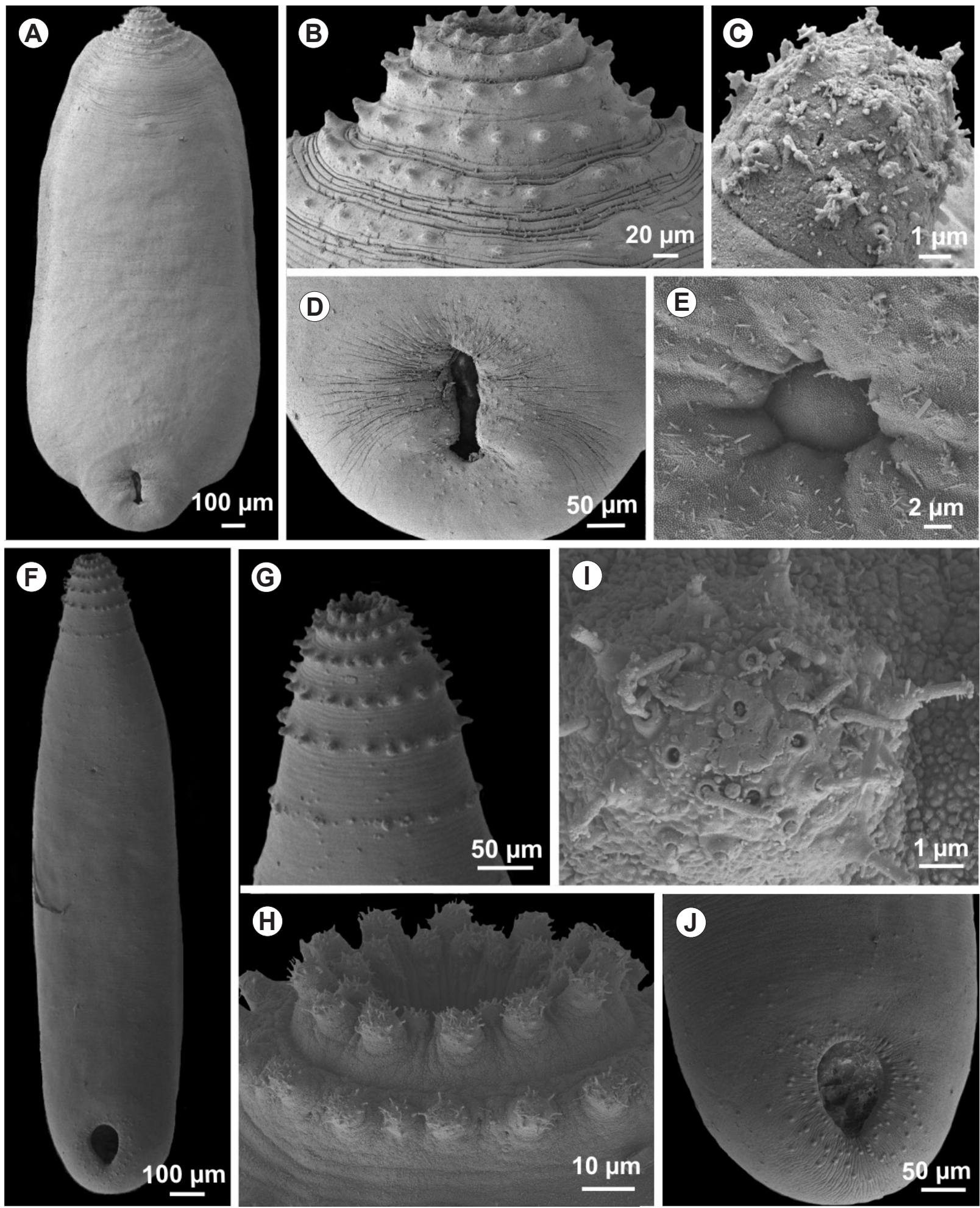

Fig. 3. A-D - Dadaytrema minimum Vaz, 1932 from Tocantinsia piresi (Miranda Ribeiro), Brazil. A - ventral view; B - anterior extremity showing distribution of papillae; $\mathrm{C}$ - single papilla on the anterior extremity; $\mathrm{D}$ - posteromedial notch in the acetabulum. E-J - Dadaytrema oxycephalum (Diesing, 1836) from Pterodoras granulosus (Valenciennes), Brazil. E - genital pore; F - ventral view; $\mathrm{G}$ - anterior extremity; $\mathrm{H}$ - anterior extremity showing distribution of papillae; I - single papilla on the anterior extremity; $\mathrm{J}$ - posteromedial notch in and papillae on the acetabulum.

The present study considerably enlarges the spectrum of definitive hosts of this species. Furthermore, it was studied using SEM for the first time, which revealed the clearly oval shape of the body (Fig. 3A). Even though many specimens are apparently contracted, the worms seem to have a similar body-shape as $D$. minimum described by Vaz (1932). The caeca are not as lateral as figured by Vaz (1932), but the worms have a rather short oesophagus, which corresponds to Vaz's (1932) description. Therefore, we consider them as conspecific. 
SEM examination also showed the presence of concentric rings of bluntly conical, multiciliate, tegumentary papillae around the anterior extremity (Fig. 3B,C) and dome-shaped, non-ciliate papillae on the rim of the acetabulum (Fig. 3D).

Dadaytrema oxycephalum (Diesing, 1836) Travassos, 1931

Fig. 3E-J

Mate rial studied: one specimen from Ageneiosus inermis (Linnaeus) (PI 886a-IPCAS D-796/1), Iquitos, Peru, 12.x.2011; one from C. macropterus (PI 101a - IPCAS D-796/2), Iquitos, Peru, 23.iv.2004, T. Scholz and R. Kuchta; four from Oxydoras niger (BR-AMP 100a,c - IPCAS D-796/3), Macapá, 24.v.2013, J. Luque, P. Vieira, T. Scholz and V. Freitas; one from $O$. niger (PI 223a - IPCAS D-796/3), Iquitos, Peru, 19.iv.2005; 24 (one hologenophore) from Piaractus brachypomus (Cuvier) (BR-AMP 72a, 73a, 87a, 107a), Macapá, 24.v.2013; 35 from P. granulosus (PI 54b, 350a,c, 441a, 443a, 758b, 783a, 829c, 831b, 999a, 1000 - IPCAS D-796/4), Iquitos, Peru, 20.iv.2004, 9.ix.2006， 15.ix.2006，3.-7.x.2011，15.iv.2018; 14 from P. granulosus (BR-MS 39c, 45b, 51a, 52b, 77b, 108a - IPCAS D-796/4), Miranda River, Pantanal, Mato Grosso do Sul, 22.23.x.2014, 25.x.2015; seven from P. granulosus (BR-PR 77b - IPCAS D-796/4), Baia River, Mato Grosso do Sul, 3.x.2014; all specimens collected by T. Scholz.

Type host: not designated by Diesing (1836) who listed the following fish hosts: 'Salmo' auratus (= Salminus brasiliensis Valenciennes) (Characiformes: Characidae), 'Salmo' pacu (= Piaractus brachypomus (Cuvier), 'Salmo' pacupeba (= Myloplus rhomboidalis (Cuvier) (Characiformes: Serrasalmidae), and 'Silurus' megacephalus (= Pimelodus ornatus Kner) (Siluriformes: Pimelodidae).

Type locality: Cuiaba, Mato Grosso, Brazil.

Type materia1: Natural History Museum in Vienna (ZMW 977, 980-984, 988; as Chiorchis oxycephalum Daday, 1907).

Additional hosts: Colossoma macropomum (Cuvier), Myleus micans (Lütken), M. asterias (Müller et Troschel), Mylosoma aureum (Spix et Agassiz), Myletes torquatus Kner, P. mesopotamicus (Holmberg) (Characiformes: Serrasalmidae); ${ }^{*}$ A. inermis, ${ }^{*} T$. piresi (Siluriformes: Auchenipteridae); *O. niger (Valenciennes), P. granulosus (Siluriformes: Doradidae); *C. macropterus, Pseudoplatystoma corruscans (Spix et Agassiz) (Siluriformes: Pimelodidae).

Site of infection: intestine.

Infection rate: A. inermis: $1 / 18$ (4); C. macropterus: $1 / 35$ (3); O. niger (Brazil): 2/2 (11; maximum 22); O. niger (Peru): 1/17 (2); P. brachypomus: 4/5 (19; maximum 25); P. granulosus (Brazil - Amapá): 6/12 (31; maximum 105); P granulosus (Brazil - Paraná): 1/5 (33); P. granulosus (Peru): 20/32 (14; maximum 49).

D i stributi on: Argentina, Brazil (states of Amapá - new locality, Amazonas, Mato Grosso, Mato Grosso do Sul - new locality, Minas Gerais, Pará, Paraná, São Paulo, Tocantins - new locality), Peru (Iquitos - new locality), Venezuela.

Representative DNA sequences: see Table 1 and Figs. 6-8.

Remarks. The species was described as $A$. oxycephalum by Diesing (1836) from several species of serrasalmid fishes and the catfish P. ornatus in Mato Grosso, Brazil. Travassos (1931) transferred it to Dadaytrema. This dige- nean seems to be the most abundant cladorchiid occurring in Neotropical fishes and occurs in a number of characiform and siluriform fishes. In the present study, four new fish hosts are reported. One specimen from $P$. granulosus (BRMS) was studied using SEM, revealing the distribution of the tegumentary papillae around the anterior extremity (Fig. 3G), where they occur in concentric rings and are conical and multiciliate (Fig. 3H,I). Dome-shaped, noncilate papillae are scattered on the acetabular rim around its aperture and on the adjacent body-surface (Fig. 3J).

\section{Deltamphistoma pitingaense Thatcher et Jégu, 1996}

Material studied: type material from INPA (see below); eight specimens from Myloplus schomburgkii (Jardine) (BRXJ 71, PAX 92, 93b, 96 - D-797/1), four from Myleus setiger Müller et Troschel (PAX 67, 68 - D-797/2), 15 from Myloplus rubripinnis (Müller et Troschel) (BRXJ73, PAX 44, 54), Xingu River in Altamira, Pará, Brazil, 20.vii.2016, J. Carneiro, J. Moreira and M.C. Moraes.

Type host: Mylesinus paraschomburgkii Jégu, Santos et Ferreira (Characiformes: Serrasalmidae).

Additional hosts: ${ }^{*} M$. schomburgkii, ${ }^{*} M$. setiger, ${ }^{*} M$. rubripinnis (Characiformes: Serrasalmidae).

Type locality: Pitinga River, Amazonas, Brazil.

Type material: holotype (INPA 191) and six paratypes (INPA 192a-f)

Site of infection: intestine.

Infection rate: Myloplus schomburgkii (Brazil): 4/6 (3); Myleus setiger (Brazil): 3/6 (3); M. rubripinnis: 3/7 (127; maximum 200).

Distribution: Brazil (Amazonas, Xingu River, Altamira, Pará, Brazil, 3³5'45"S; 5149'01"W - new locality).

Representative DNA sequences: not available.

Remarks. New material from three serrasalmid fishes (all new hosts) well corresponds in its morphology to the type and only species of Deltamphistoma Thatcher et Jégu, 1996, D. pitingaense Thatcher et Jégu, 1996. This species was described from $M$. paraschomburgkii from three rivers in the state of Amazonas, Brazil by Thatcher and Jégu (1996). It closely resembles Anavilhanatrema robustum Thatcher, 1992 (the original spelling "robusta" is emended here because the latin suffix -trema is neuter in gender, not feminine) described from the serrasalmid Pristobrycon striolatus (Steindachner) in Anavilhana Island, Rio Negro, Amazonas, Brazil in the possession of large, tandem testes much wider than long, extramural pharyngeal sacs and intercaecal uterus, but differs by the absence of the anterior collar-like ridge (present in A. robustum), the presence of an oesophageal bulb, postbifurcal genital pore, intestinal caeca ending far from the acetabulum, an entire, not lobed ovary, and intercaecal vitelline follicles (see Jones 2005b).

Doradamphistoma bacuense Thatcher, 1999

Figs $1 C, D, 4 C, D, E$

Material studied: type material (see below); five specimens from Megalodoras uranoscopus (PI 324b, 344, 581, 
1077, 1084 - IPCAS D-798/1), Iquitos, Peru, 7.ix.2006 and 23.iv.2018, T. Scholz and R. Kuchta; two from M. uranoscopus (PAX 75, 76), Xingu River in Altamira, Pará, 22.vii.2016, J. Carneiro, M.C. Moraes and J. Moreira; five from Oxydoras niger (PEOX 01, 02 - IPCAS D-798/2), Tarapoto, San Martín, Peru, 13.iv.2016, C. Cruces and J. Chero; one from Platydoras costatus (Linnaeus) (PI 353a - D-798/3), Iquitos, Peru, 9.ix.2006, T. Scholz and R. Kuchta.

Type host: Megalodoras irwini (= M. uranoscopus) (Siluriformes: Doradidae).

Type locality: Manaus, Amazonas, Brazil.

Type material: Holotype and five paratypes (INPA 371, $372 \mathrm{a}-\mathrm{e})$.

Additional (new) hosts: *Oxydoras niger, *Platydoras costatus (Siluriformes: Doradidae).

Site of infection: Intestine.

Infection rate: M. uranoscopus (Brazil): 2/3 (3); M. uranoscopus (Peru): 5/7 (3; maximum 9); O. niger (Peru): 2/2 (9); P. costatus (Peru): 1/1 (3).

D i s tri buti on: Brazil (Amazonia; Xingu River, Pará - new locality), Peru (Tarapoto, San Martín Region, 6²2'S; $76^{\circ} 22^{\prime} \mathrm{E}$ - new locality).

Representative DNA sequences: see Table 1 and Figs. 6-8.

Remarks. This species was described from $M$. irwini (= M. uranoscopus) from Manaus in the state of Amazonas in Brazil, and a new genus, Doradamphistoma Thatcher, 1999, was erected to accommodate it by Thatcher (1999). He characterised it by well-developed pharynx and extramural pharyngeal sacs, a long oesophagus, sinuous caeca approaching the anterior margin of the acetabulum, testes diagonal, equatorial or pre-equatorial, postbifurcal genital pore, and postequatorial ovary (figured as anterior to the caecal ends).

The only differences between Thatcher's (1999) description of $D$. bacuense and the present specimens are the presence of an anterior pharyngeal sphincter, which he did not report or illustrate, and the shape of the acetabulum, which has a posteromedial notch (Figs 1D, 4E) not described by Thatcher but confirmed by a study of the type material (Fig. 1D). Our material from Brazil and Peru expands the spectrum of definitive hosts to include another two species of doradid catfishes, namely $O$. niger and $P$. costatus. Peru represents a new geographical record for the species, previously known only from the Amazon River basin. Additional specimens also enabled us to provide the first SEM of the species. Concentric rings of inconspicuous dome-shaped papillae are present around the oral opening, extending further posteriorly, and more widely spaced, on the anterior extremity, and on the rim of the acetabulum; none were observed around the genital pore. The molecular data indicate a close relationship between D. bacuense and Dadaytremoides parauchenipteri, a parasite of auchenipterid and pimelodid catfishes (see below).
Doradamphistoma parauchenipteri (Lunaschi, 1989)

comb. n.

Fig. 4A-B

Syn. Dadaytremoides parauchenipteri Lunaschi, 1989

M a t e r i l 1 studied: one specimen from Ageneiosus inermis (PI886) and six from T. galeatus (PI 436, 799, 803, 820), Iquitos, Peru, 3.x.2011, T. Scholz; two from Brachyplatystoma vaillantii (Valenciennes) (BR-AMP59), Macapá, Amapá, Brazil, 16.x.2017, C. Pantoja; 15 from Trachelyopterus galeatus (PAIA 64, 123, 124, 125, 126, 145, 146, 160, 161, 163, 164, 166, 168, 187, 198), Maracanã River at Igarapé-açu, Pará, Brazil, 16.vii.2016, C. Pantoja; 13 from T. galeatus (BR-PR 25, 26, 41, 65, 66, 67, 71, 72, 82, 84, 142, 221), Paraná River in Porto Rico, Paraná, Brazil, 2.ii.2014, T. Scholz.

Type host: Trachelyopterus galeatus (Siluriformes: Auchenipteridae).

Type locality: Arroyo Brazo Chico, Uruguay River basin, Entre Ríos Province, Argentina.

Type material: type specimens (three specimens, all flattened) in the Colección Helmintológica, Museo de La Plata, Argentina (Coll. Nos. 1315C and 1316C).

Additional hosts: *A. inermis, Trachelyopterus coriaceus Valenciennes (Siluriformes: Auchenipteridae); ${ }^{*}$ B. vaillantii (Siluriformes: Pimelodidae).

Site of infection: intestine.

Infection rate: A. inermis (Peru): $1 / 1$ (1); B. vaillantii (Brazil): 1/4 (2); T. galeatus (Pará, Brazil): 15/25 (2); T. galeatus (Paraná, Brazil): 12/16 (4; maximum 27); T. galeatus (Peru): 13/24 (2).

Distribution: Argentina (Entre Ríos Province), Brazil (Igarapé Fortaleza River, Macapá, Amapá, 0002'20"N; 5103'59"W - new locality; Maracanã River, Igarapé-açu, Pará $01^{\circ} 07^{\prime} 44^{\prime \prime} \mathrm{S}$; $47^{\circ} 37^{\prime} 12^{\prime \prime} \mathrm{W}$ - new locality; Paraná River, Porto Rico, Paraná, $20^{\circ} 45^{\prime} \mathrm{S}$; 531' $\mathrm{W}$ - new locality); Peru (Iquitos, Loreto - new locality).

Representative DNA sequences: see Table 1 and Figs. 6-8.

Remarks. The species was described from Parauchenipterus galeatus (= Trachelyopterus galeatus) from Argentina by Lunaschi (1989). It is characterised by a large pharynx with a massive anterior sphincter, extensive uterus with numerous extracaecal loops from the oesophageal level to the acetabulum, a posteromedial notch in the acetabular rim, testes diagonal, and few vitelline follicles situated far anterior to the acetabulum (Lunaschi 1989). Numerous specimens were found in the type host, T. galeatus, from the Paraná and Amazon River basins, and in two new definitive hosts, both of the order Siluriformes, i.e. the auchenipterid $A$. inermis and the pimelodid $B$. vaillantii.

Using SEM (Fig. 4A), dome-shaped non-ciliate papillae in concentric rings around the anterior extremity were clearly observed (Fig. 4B); the rings, more widely spaced, extend posteriorly along the anterior extremity but, as with the previous species, do not reach the level of the genital pore; small dome-shaped papillae are also present on the acetabulum (Fig 4A-B). 


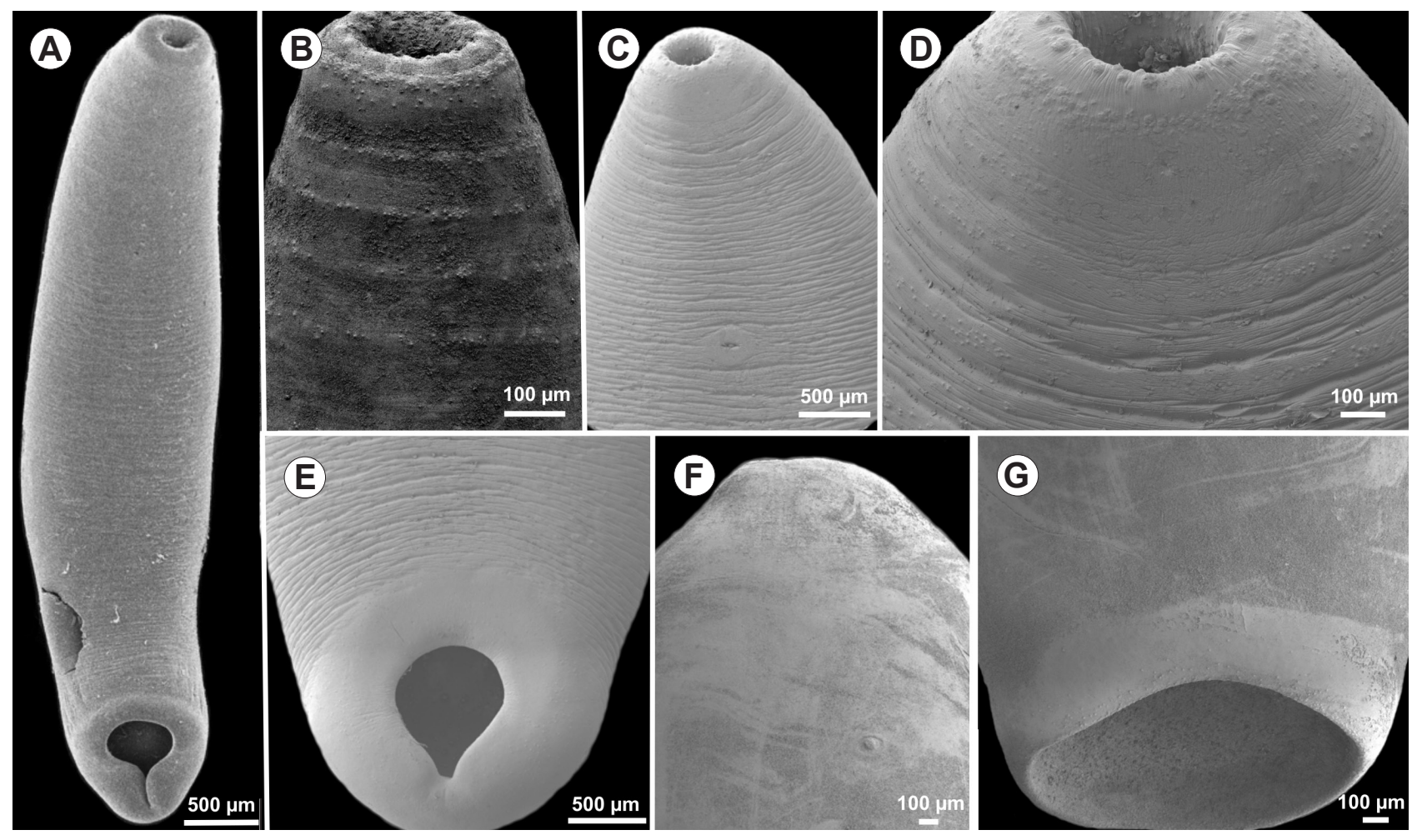

Fig. 4. A, B - Doradamphistoma parauchenipteri (Lunaschi, 1989) comb. n. from Trachelyopterus galeatus (Linnaeus), Brazil (A-B), A - ventral view; B -anterior extremity showing distribution of papillae. C, D, E - Doradamphistoma bacuense Thatcher, 1999 from Megalodoras uranoscopus (Eigenmann et Eigenmann), Brazil; C - anterior region with oral opening and genital pore; D -anterior region showing distribution of papillae; $\mathrm{E}$ - posteromedial notch in the acetabulum. F, G-Pseudocladorchis romani sp. $\mathrm{n}$. from Pterodoras granulosus (Valenciennes), Peru; F - anterior region showing the genital pore; $\mathrm{G}$ - acetabulum; posteromedial notch absent.

Although Dadaytremoides parauchenipteri and Doradamphistoma bacuense were originally assigned to two distinct genera, they share some characteristics, discussed in more detail below. Both species seem to share a similar distribution of the tegumentary papillae. Although there are deficiencies in the original descriptions of both species and the type species of Dadaytremoides, D. grandistomis Thatcher, 1979, some clarifications have been possible by examination of the types and additional specimens from the Peru/Brazil collections.

Lunaschi (1989) described D. parauchenipteri and compared it only with $D$. grandistomis, the only option open to her at that time. Ten years later, Thatcher (1999) erected Doradamphistoma, compared it only with Pacudistoma turgida Thatcher, 1992 and was presumably unaware of Lunaschi's (1989) work because he did not, then or in his 2006 book, list the taxon originally erected as Dadaytremoides parauchenipteri as a species of Dadaytremoides or include any references by L.I. Lunaschi.

Doradamphistoma bacuense and Dadaytremoides parauchenipteri resemble each other to a degree that suggests they are congeneric but may differ at species level. They resemble each other in: the pharynx with an anterior pharyngeal sphincter (this differentiates both species from $D$. grandistomis, in which it was neither reported by Thatcher 1979 nor observed in the type material); extramural pharyngeal sacs; well-developed oesophagus and presence of an oesophageal bulb. The caeca terminate close to or not far short of the acetabulum in both (but far short in D. grandis- tomis). The genital pore is bifurcal to closely postbifurcal. The testes in both are diagonal, entire to slightly lobed or indented. The ovary is not between the caecal ends as in $D$. grandistomis but some distance anterior to them; it is close to the testes in D. parauchenipteri but far removed from them in D. bacuense and in Dadaytrema grandistomis. The uterus is intercaecal in $D$. grandistomis but encroaches right across the caeca in D. parauchenipteri and D. bacuen$s e$. The vitelline fields in $D$. grandistomis are clustered at the ends of the caeca. In D. parauchenipteri, they are clearly anterior to the caecal ends, closely posterior to the ovary, in more or less horizontal fields. In D. bacuense, they are in the ovarian zone and clearly anterior to the caecal ends as in D. parauchenipteri but in longitudinal fields. A posteromedial acetabular notch is present in D. parauchenipteri and $D$. bacuense but not in $D$. grandistomis.

The indications are that in morphological characters $D$. parauchenipteri and D. bacuense have more in common with each other than either does with $D$. grandistomis. The differences between the two of them are the position of the ovary relative to the testes and the configuration - horizontal or longitudinal - of the vitelline fields. These differences would be sufficient to separate them at species level on morphological terms (unless some of them could be shown to be artefacts related to fixation or maturity).

DNA sequences are available for $D$. parauchenipteri and $D$. bacuense, which are very close by any criteria, but not for D. grandistomis, the type species of Dadaytremoides, which differs from both by several morpholog- 
ical characters. A genus rests on its type species, not on others attributed to it, and D. grandistomis differs from the others in a combination of the characters listed above.

Therefore, the attribution of $D$. parauchenipteri to $D a$ daytremoides is now unsure on morphological grounds and the species should be transferred to Doradamphistoma as a new combination. This fits with the sequencing results for both species of that genus (Figs 6-8). Although both genera are morphologically similar, which resulted in them keying out in the same couplet in the key by Jones (2005b), they are not synonymised in the absence of any DNA sequence data from the type species of Dadaytremoides and the morphological differences discussed above.

\section{Myleustrema concavatum Thatcher et Jégu, 1998}

Fig. 5A

Material studied: type material (see below); one specimen from Myloplus rubripinnis (BRXJ 77 - D-799/1), Xingu River in Altamira, Pará, Brazil, 19.vii. 2016, J. Carneiro.

Type host: Myleus ternetzi (Norman) (Characiformes: Serrasalmidae).

Type locality: French Guiana.

Ty p e materia 1: holotype INPA 206, paratypes INPA 207a-d. Additional host: ${ }^{*} M$. rubripinnis (Characiformes: Serrasalmidae)

Site of infection: intestine.

Infection rate: M. rubripinnis: $1 / 3$ (9).

Distribution: Brazil (Xingu River, Pará - new locality), French Guiana.

Representative DNA sequences: not available.

Remarks. Specimens found in Myloplus rubripinnis are almost indistinguishable from those described by Thatcher and Jégu (1998) as Myleustrema concavatum and are considered conspecific. The species was described from Myleus ternetzi in French Guiana and never found since its original description. It is typified by an ovoid, thick-walled cirrus-sac and the aperture of the acetabulum directed posteriorly, with tiny papillae on its rim. In addition, it has a postbifurcal genital pore, pharynx with long extramural sacs, lobed oblique testes much wider than long, and short lateral fields of vitelline follicles commencing posteriorly at the level of the ovary but failing to reach the level of the posterior testis.

The only difference between our specimens and those of Thatcher and Jégu (1998) is that the caeca are conspicuously more sinuous in the dorsoventral plane. LM and SEM observation confirmed the presence of concentric circles of papillae around the anterior extremity (Fig. 5A), those in the first five circles being more conspicuous. $\mathrm{Nu}-$ merous papillae were also observed on the acetabular rim, especially dorsally, as also mentioned in the original description (Thatcher and Jégu 1998).
Subfamily Kalitrematinae Travassos, 1933

Pseudocladorchis romani sp. n.

Figs 4D,G, 5B-D

ZooBank number for species:

urn:1sid:zoobank.org:act:22BCF69E-4A0E-421B-8555-B7D406461732

Material studied: three specimens from Brachyplatystoma vaillantii (PI 789a), Río Nanay near Iquitos, Peru, 23.iv.2011 (IPCAS D-801/2); one from Calophysus macropterus (PI 101a), Iquitos, Peru, 23.iv.2004 (IPCAS D-801/3); 28 from Pterodoras granulosus (PI 350a, 441a, 759a, 783a, 829a, 830a, 1000, 1001, 1076), Iquitos, Peru, 9. and 15.ix.2006 (IPCAS D-801/1); three from Oxydoras niger (PI 223a), Iquitos, Peru, 19.iv.2005 (IPCAS D-801/4); one from Megalodoras uranoscopus (BRX 36b), Xingu River in Altamira, Pará, Brazil, 24.iv.2013.

Des cription (based on seven specimens; measurements of specimens from different hosts are in Table 3): Paramphistomatoidea, Cladorchiidae, Kalitrematinae. Body subcylindrical, slightly tapered at each extremity. Dome-shaped tegumentary papillae present around oral opening and on anterior extremity to level of pharynx and on rim of acetabulum. Acetabulum lacks a posteromedial notch in dorsal rim. Oral opening terminal. Pharynx with anterior and posterior sphincters and tiny paired primary intramural sacs. Oesophagus fairly straight or slightly flexed; oesophageal bulb or thickening not clearly seen. Caecal bifurcation in anterior third of body. Caeca end short of acetabulum. Testes symmetrical or subsymmetrical, irregular, usually overlie caeca. Cirrus-sac oval, contains internal seminal vesicle and prostatic cells, closely postbifurcal. Genital pore bifurcal, surrounded by glandular tissue. Ovary between caecal ends, subspherical, as large as or, usually, larger than testes. Laurer's canal not seen. Vitelline follicles in lateral fields along caeca from level of ovary but not reaching level of testes anteriorly; transverse vitelline ducts occasionally visible as loop posterior to ovary. Mehlis' gland complex posteroventral to ovary. Uterus forms descending limb; it and ascending limb cross caeca into extracaecal space from postovarian zone to bifurcal level. Eggs numerous. Excretory vesicle and pore not seen.

Ty pe host: Pterodoras granulosus (Siluriformes: Doradidae). Additional hosts: O. niger (Siluriformes: Doradidae); B. vaillantii, C. macropterus (Siluriformes: Pimelodidae), $M$. uranoscopus (Siluriformes: Doradidae).

Ty p e lo c a lity: Iquitos, Loreto Region, Peru (Amazon Riv-

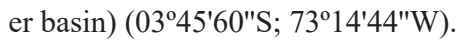

Additional lo cality: Brazil (state of Pará-Xingu River).

Site of infection: intestine.

Infection rate: B. vaillantii: $1 / 1(7) ;$ C. macropterus: $1 / 35$ (1); P. granulosus: 18/32 (2; 3); O. niger: $1 / 18$ (3); M. uranoscopus: $1 / 2$ (1).

Type material: holotype from $P$. granulosus (PI 350a), Iquitos, Peru, collected on 9.ix.2006 (IPCAS D-801/1); one paratype from P. granulosus (PI 441a), Iquitos, Peru, 15.ix.2006 (IPCAS D-801/1); two paratypes from P.granulosus (PI 783a), Iquitor, Peru, 4.x.2011 (CHIOC 40059a,b); one paratype from O. niger (PI 223a), Iquitos, Peru, 19.iv.2005 (IPCAS D-801/4). 

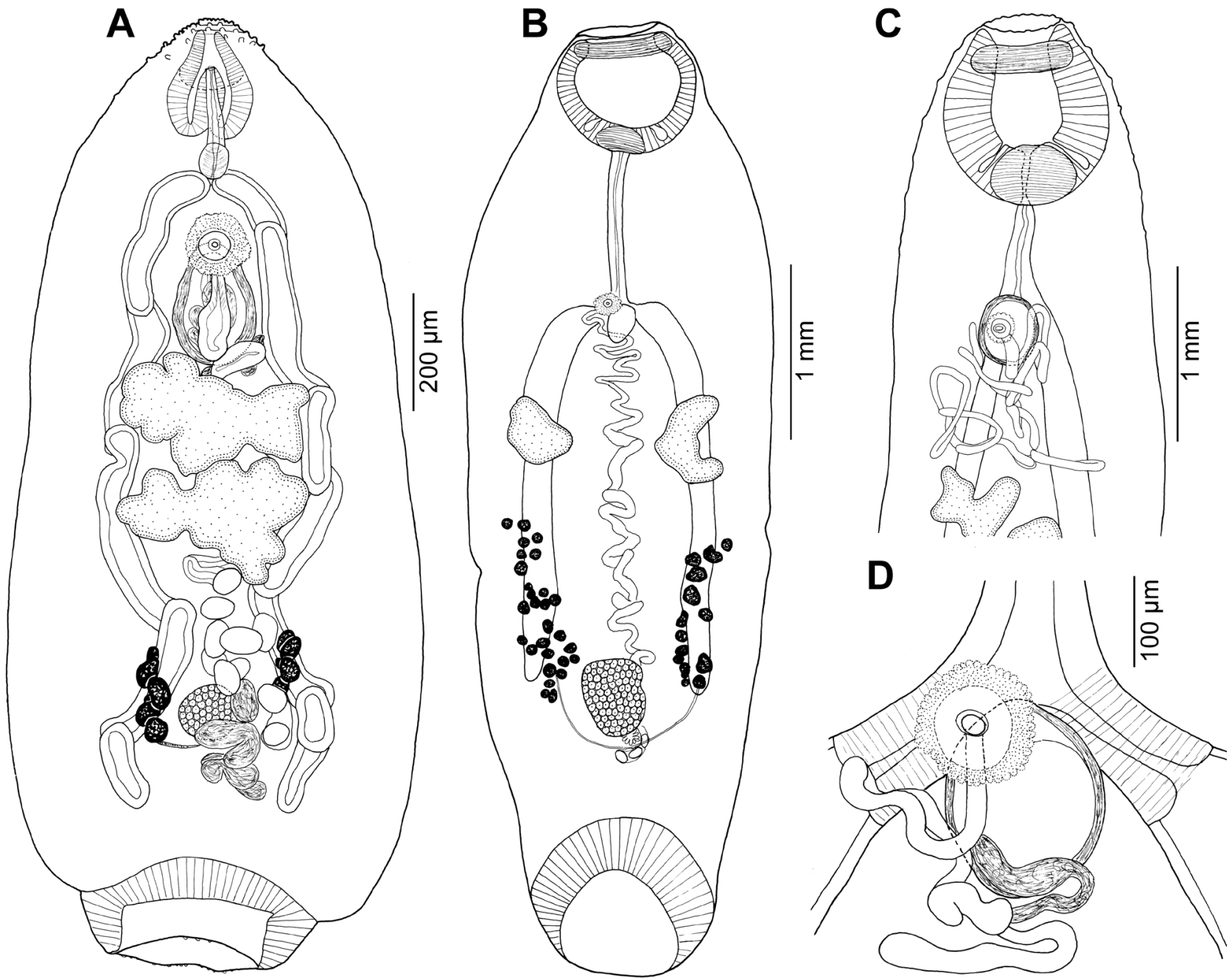

Fig. 5. A - Myleustrema concavatum (Thatcher et Jégu, 1998) from Myloplus rubripinnis (Müller et Troschel), Brazil. A - ventral view. B-D - Pseudocladorchis romani sp. n. from Pterodoras granulosus (Valenciennes), Peru (B, D) and Oxydoras niger (Valenciennes), Peru (C). B - ventral view of holotype (IPCAS D-801/1); C - anterior region with genital pore, ventral view of paratype (IPCAS D-801/4); D - terminal genitalia of holotype (IPCAS D-801/1).

Table 3. Measurements of Pseudocladorchis romani sp. $\mathrm{n}$. from different hosts in Peru (in micrometres unless otherwise stated).

\begin{tabular}{|c|c|c|c|}
\hline Host & Pterodoras granulosus & Calophysus macropterus & Oxydoras niger \\
\hline Collection No.* & IPCAS D-801/1 & IPCAS D-801/3 & IPCAS D-801/4 \\
\hline Specimens & 5 & 1 (immature) & 1 \\
\hline Total length $(\mathrm{mm})$ & $5.02-8.21\left(6.6^{* *}\right)$ & 1.08 & 5.74 \\
\hline Maximum width (mm) & $1.68-2.88(2.35)$ & 0.32 & 1.57 \\
\hline Acetabulum length & $752-1,463(1,124)$ & 222 & 1,038 \\
\hline Acetabulum width & $876-1,524(1,298)$ & 268 & 1,064 \\
\hline Pharynx length & 634-777 (714) & 292 & 955 \\
\hline Pharynx width & 629-988 (838) & 243 & 927 \\
\hline Oesophagus & $798-1,473(1,166)$ & 109 & 540 \\
\hline Oesophageal bulb & $156-198$ & - & - \\
\hline Caecal bifurcation to anterior extremity (mm) & $1.09-2.00(1.5)$ & 0.87 & 2.88 \\
\hline Caecum (right) (mm) & $2.35-4.74(3.18)$ & 0.37 & 2,69 \\
\hline Caecum (left) (mm) & $2.35-4.72(3.21)$ & 0.36 & 2,81 \\
\hline Anterior testis length & $162-421(344)$ & 181 & 181 \\
\hline Anterior testis width & $201-544(350)$ & 459 & 459 \\
\hline Posterior testis length & $187-619(388)$ & 424 & 424 \\
\hline Posterior testis width & $208-506(341)$ & 254 & 254 \\
\hline Ovary length & $174-427(342)$ & 35 & 342 \\
\hline Ovary width & $123-669(320)$ & 61 & 320 \\
\hline
\end{tabular}

*Helminthological Collection of the Institute of Parasitology of the Biology Centre of the Czech Academy of Sciences, České Budějovice, Czech Republic; **mean 


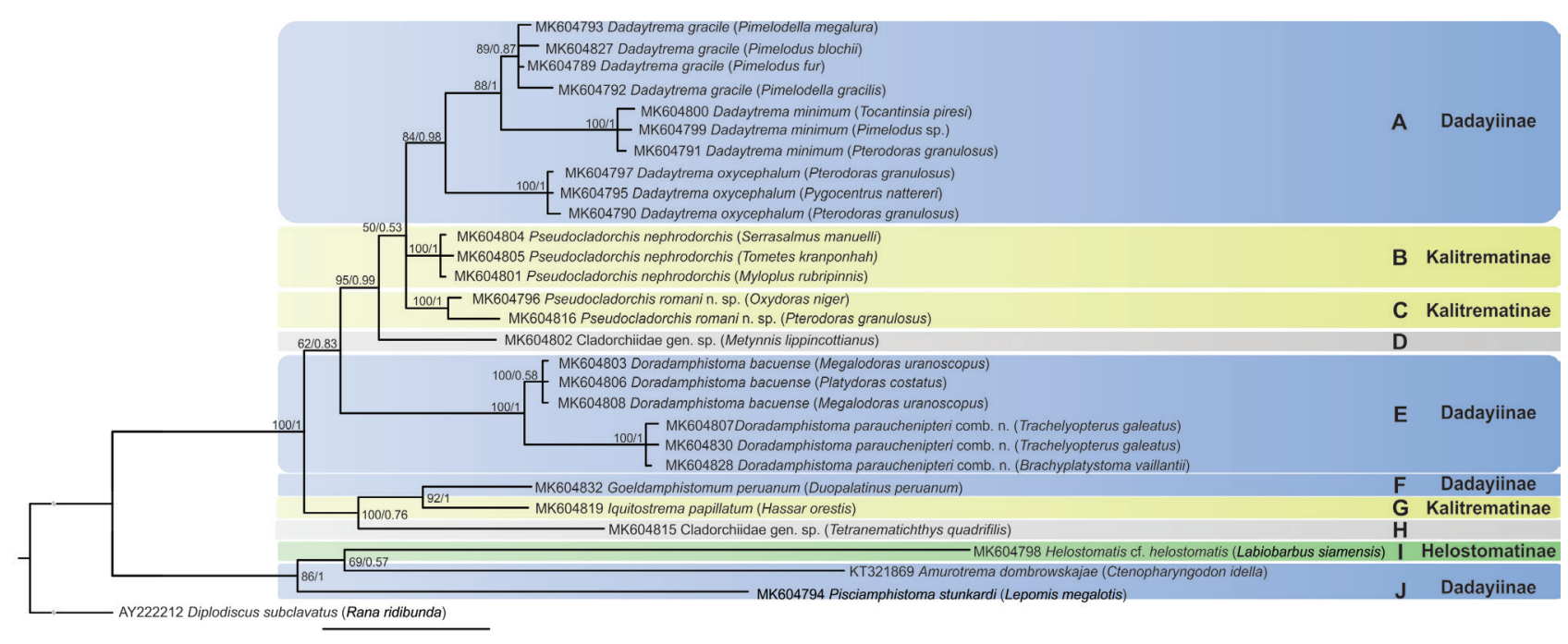

Fig. 6. Bayesian tree from phylogenetic analysis of the sequences of $28 \mathrm{~S}$ rDNA from cladorchiids parasitic in freshwater fishes from Brazil and Peru. Numbers show bootstrap nodal support (maximum likelihood $-1,000$ replications) and Bayesian posterior probability ( $4 \times 10^{6}$ generations; burn-in $=4 \times 10^{3}$ ). Diplodiscus subclavatus (Pallas, 1760) from Pelophylax ridibundus (Pallas) (formerly Rana ridibunda) was used as outgroup.

Etymology: The species is named in honour of Roman Kuchta, Institute of Parasitology, Czech Republic for his contribution to a better understanding of the diversity of fish helminths in Amazonia.

Representative DNA sequences: see Table 1 and Figs. 6, 7.

Differential diagnosis. The new species is morphologically very similar to Pseudocladorchis nephrodorchis Daday, 1907 (see below). However, in P. nephrodorchis, the testes have a distinctive exaggerated reniform shape with lobes which are usually orientated towards the ventral surface. Furthermore, the ovary in the present specimens is almost always as large as, or larger than, the testes. The specimens also differ from $P$. cylindricus in these respects and in lacking a posteromedial notch in the acetabulum. These differences are considered sufficient to designate a new species on morphological grounds and molecular data also support its validity (see Fig. 6).

\section{Pseudocladorchis nephrodorchis Daday, 1907}

Material studied: one specimen from Leporinus affinis Günther (PAX 20), Xingu River in Altamira, Pará, Brazil, 23.ix.2013, F.B. Pereira and P.V. Alves (IPCAS D-802/1); one from Metynnis lippincottianus (PAIA 06f), Maracanã River, Igarapé-açu, Pará, Brazil, 13.vii.2016, C. Pantoja; one from Myleus setiger (PAX 67); two from M. rubripinnis (BRXJ73; PAX 44, 54 - IPCAS D-802/ 2); two from M. schomburgkii (Jardine) (BRXJ 71, PAX 92); one from Serrasalmus manueli (Fernández-Yépez et Ramírez) (PAX 61 - IPCAS D-802/4); four from Tometes kranponhah (BRXJ 05, PAX 42 - IPCAS D-802/5); two from Ossubtus xinguense Jégu (BRXJ 01 IPCAS D-802/3), all Xingu River in Altamira, Pará, Brazil, 20.vii. 2016, J. Carneiro, J. Moreira and M.C. Moraes.

Type host: not designated by Daday (1907) who mentioned three fish hosts: 'Salmo' sp., 'Salmo' pacu (= Piaractus brachypomus Cuvier) and 'Salmo' pampa (= Mylossoma aureum (Spix et Agassiz).
Type locality: not explicitly mentioned, but most likely Paraná or Paraguay River, Mato Grosso, Brazil (based on data in Diesing 1836).

Type material: Natural History Museum in Vienna (ZMW 980). Additional hosts: *Leporinus affinis (Characiformes: Anostomidae), ${ }^{*}$ M. lippincottianus, ${ }^{*}$ Myleus setiger, ${ }^{*} M$. rubripinnis, *M. schomburgkii, *Ossubtus xinguense, *Serrasalmus manueli, *Tometes kranponhah (Characiformes: Serrasalmidae).

Distribution: Brazil (states of Paraná or Mato Grosso; Marapanim River, Igarapé-açu, Pará - new locality; Xingu River in Altamira, Pará - new locality).

Site of infection: intestine.

Infection rate: L. affinis: $1 / 3$ (2); M. lippincottianus: 1/16 (1); M. setiger: $1 / 6$ (2); M. rubripinnis: $2 / 7$ (1); M. schomburgkii: 2/6 (3); S. manueli: 1/4 (2); T. kranponhah: 2/3 (4); O. xinguense: $1 / 1$ (2).

Representative DNA sequences: see Table 1 and Fig. 6.

Remarks. Specimens found in several species of serrasalmid fishes are placed in Pseudocladorchis Daday, 1907 because they possess characteristics typical of the genus (see Jones 2005b), e.g. a large pharynx with anterior and posterior sphincters and intramural sacs, testes symmetrical or nearly so, overlying caeca ventrally, vitelline follicles in restricted lateral fields from about the testicular level to near or beyond the caecal ends, and a bifurcal genital pore.

The genus was erected by Daday (1907) to accommodate three species collected by J. Natterer in Brazil and then described by Diesing (1836), namely Amphistoma cylindricum Diesing, 1836 (listed first and thus considered to be the type species; see Jones 2005b), P. nephrodorchis and P. macrostomus Daday, 1907. Even though Daday (1907) provided detailed morphological descriptions of all three species, there was in fact no explicit differential diagnosis. As indicated by the species name, $P$. nephrodorchis has testes of a distinctive reniform shape, which differs significantly from the testes of the other species. 


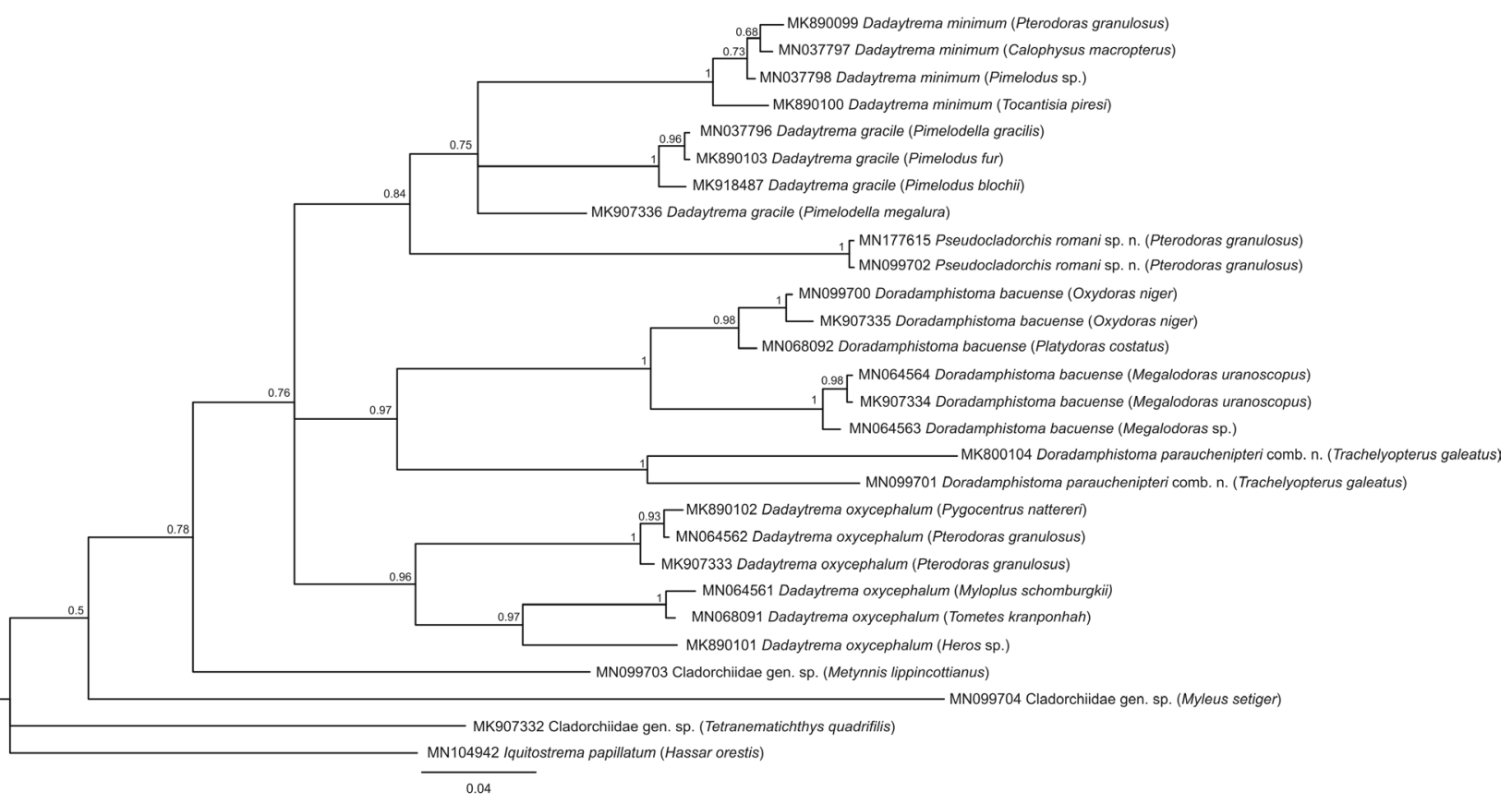

Fig. 7. Bayesian tree from phylogenetic analysis of the sequences of cox $1 \mathrm{mtDNA}$ from cladorchiids parasitic in freshwater fishes from Brazil and Peru. Numbers show Bayesian posterior probability $\left(4 \times 10^{6}\right.$ generations; burn-in $\left.=4 \times 10^{3}\right)$. The tree was generated without outgroup.

Stunkard (1925) synonymised all three species with $P$. cylindricus because he did not consider differences between P. cylindricus, P. nephrodorchis and P. macrostomus to be significant at species level. Comparison of the original text of Daday (1907) and his figures on plates 25 and 26 has revealed that P. cylindricus (Diesing, 1836) and P. macrostomus Daday, 1907 have a posteromedial notch in the posterior rim of the acetabulum ("Die Öffnung des Saugnapfs ist in der Regel kreisförmig, am hintern Rand zeigt sich indessen häufig eine kleine Vertiefung"; see figs. 7 and 9 of $P$. cylindricus on plate 25; "Die Öffnung des Saugnapfs blickt schief nach hinten und gegen den Bauch"; see fig. 8 on plate 26 of Daday 1907 for P. macrostomus).

In contrast, $P$. nephrodorchis has an acetabulum without a posteromedial notch ("vom Bauch gesehen hingegen einem ganzen Kreis bzw. einem breiten Ring (Taf. 25, Fig. 18, 20; Taf. 26, Fig. 1)."). Based on this difference, $P$. macrostomus is retained as a junior synonym of P. cylindricus as first proposed by Stunkard (1925) but P. nephrodorchis is considered to be valid. The description of P. nephrodorchis was based on Diesing's (1836) specimens designated as Amphistomum oxycephalum on slides Nos. 980 (from 'Salmo' sp.), 981 (from 'Salmo' pacu $=$ Myletes bidens) and 983 ('Salmo' pampa $=$ Myletes aureus).

The acetabulum of our specimens lacks the deep posteromedial notch typical of $P$. cylindricus. Therefore, they are indistinguishable from $P$. nephrodorchis (see above) in this respect. Furthermore, specimens lacking this character also have reniform testes, as indicated by Daday's (1907) choice of the species name.
Betamphistoma jariense Thatcher et Jégu, 1996

Material studied: type material (see below); one specimen from Tometes kranponhah Andrade, Jégu et Giarrizzo (PAX 42), Xingu River in Altamira, Pará, Brazil, 17.vii. 2016, J. Moreira and M.C. Moraes (IPCAS D-800/1).

Type host: Mylesinus paraschomburgkii (Characiformes: Serrasalmidae).

Type locality: Jarí River, Pará, Brazil.

Type materia l: holotype INPA 187, paratypes INPA 188a-f. Site of infection: intestine.

Infection rate: 1/2 (10).

Additional (new) host: *T. kranponhah (Characiformes: Serrasalmidae).

Distribution: Brazil (Pará including Xingu River - new locality).

Representative DNA sequences: not available.

Remarks. Betamphistoma jariense was described from M. paraschomburgkii by Thatcher and Jégu (1996) as the type and only species of Betamphistoma Thatcher et Jégu, 1996. Cladorchiids found by the present authors in the same region (state of Pará) correspond to $B$. jariense in most morphological characteristics, i.e. a dorsoventrally flattened body, small oesophageal bulb, short caeca, a postbifurcal genital pore, a large, thick-walled cirrus-sac, and vitelline follicles limited in extent (see Thatcher and Jégu 1996).

\section{Phylogenetic relationships of cladorchiid trematodes from freshwater fishes}

In total, 66 sequences of three molecular markers of 39 isolates from 26 hosts were generated (Table 1; Figs. 6-8). The phylogenetic trees for $28 \mathrm{~S}$ and ITS 2 rDNA showed 


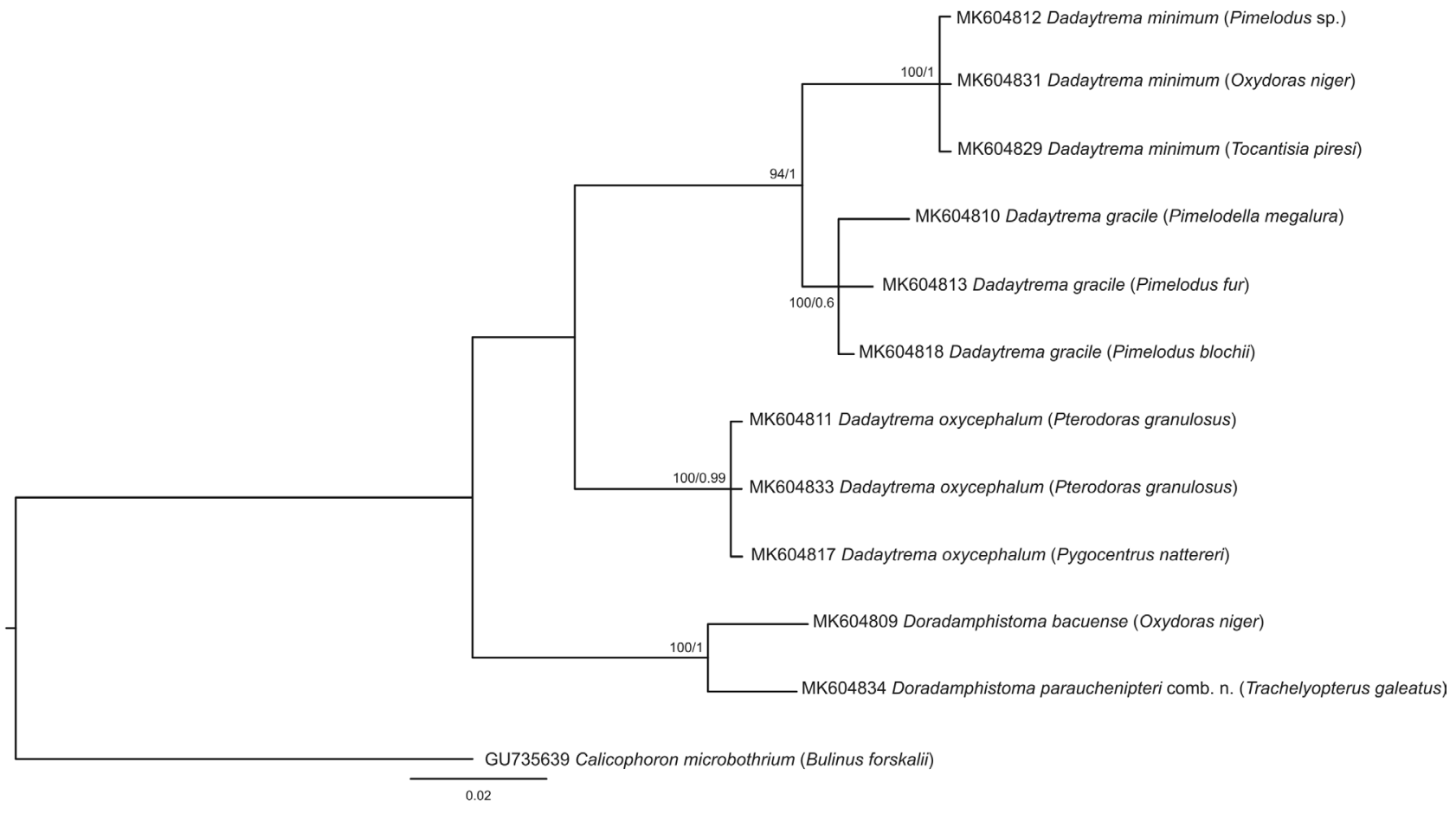

Fig. 8. Bayesian tree from phylogenetic analysis of the sequences of ITS2 rDNA from cladorchiids parasitic in freshwater fishes from Brazil and Peru. Numbers show bootstrap nodal support (maximum likelihood $-1,000$ replications) and Bayesian posterior probability $\left(4 \times 10^{6}\right.$ generations; burn-in $=4 \times 10^{3}$ ). Calicophoron microbothrium (Fischoeder, 1901) from Bulinus forskalii Ehrenberg was used as outgroup.

the congruent topology, even though $28 \mathrm{~S}$ rDNA analysis included more taxa (Fig. 6). Molecular data revealed neither the Dadayiinae nor the Kalitrematinae as monophyletic and two species of the Kalitrematinae belong to two separate lineages (Fig. 6).

Several well-supported lineages could be distinguished based on molecular data, especially the 28S rDNA sequence dataset (see Fig. 6 for designation of individual clades). The clade A comprises three morphologically similar, but genetically distinct species of Dadaytrema which forms a monophyletic assemblage. The clades B and C include two morphologically similar species of Pseudocladorchis, which differ from one another only slightly (nucleotide divergence about $1 \%$ in $28 \mathrm{~S}$ rDNA dataset), but they occur in different fish groups: $P$. nephrodorchis in characiform fishes, whereas $P$. romani sp. n. has been found only in siluriform fishes.

Two samples provisionally designated as Cladorchiidae gen. sp. 1 (clade D) and Cladorchiidae gen. sp. 2 (clade G) were revealed in analyses inferred from 28S rRNA gene sequences (Fig. 6). Unfortunately, hologenophores of these samples were not available for a more precise identification of these samples that undoubtedly represent separate species and possibly belong to new genera.

The well-supported clade E comprises species originally placed in two morphologically similar genera, $D$. bacuense and D. parauchenipteri (transferred to Doradamhistoma as D. parauchenipteri comb. n.; see Remarks to both species above), both occurring in catfishes (doradids in the former species and auchenipterids and pimelodids in the latter). Molecular data indicate that these species are congeneric, thus supporting the new combination proposed for
D. parauchenipteri based on morphological characteristics (see above). Nucleotide divergence between specimens of both species is rather low (only $2 \%$ in $28 \mathrm{~S}$ rDNA sequences), corresponding to differences between species of the same genus (unpublished data).

Another well-supported clade called F in Fig. 6 is composed by Iquitostrema papillatum and Goeldamphistoma amazonum, two species recently described from Peruvian Amazonia. Nucleotide divergence between these species of two morphologically conspicuously different genera, Iquitostrema and Goeldamphistomum, was only $2 \%$ in $28 \mathrm{~S}$ rDNA sequences, whereas the divergence between the species of Dadaytrema ranged from 2-4\%. However, there may be different rates of divergence for different lineages and species pairs or species groups. This depends on a range of historical factors such as age, selection pressures, drift, stasis, etc.

Clade I is a sister clade to all Neotropical cladorchiids, which thus form a monophyletic assemblage. This clade is composed of three non-Neotropical cladorchiids, namely Amurotrema dombrowskajae from the Palaearctic region, Helostomatis cf. helostomatis from the Indomalayan region, and Pisciamphistoma stunkardi from the Nearctic region. The latter species from North American centrarchids is a sister to the clade containing both taxa from the Old World. Clade I is a sister clade to all Neotropical cladorchiids (clades A-G), which thus form a monophyletic assemblage.

\section{DISCUSSION}

The present study provides an account of 14 species of cladorchiids found in freshwater fishes in South America 
(Brazil and Peru), with numerous new host (29) and geographical (8) records. In addition, three new species are described and scanning electron micrographs of seven species are provided, five for the first time. However, the most important advance of the present study is the first assessment of the phylogenetic relationships of Neotropical cladorchiids.

In the most comprehensive molecular phylogenetic study of digeneans at family level, Olson et al. (2003) included only two species of the superfamily Paramphistomoidea, namely Solenorchis travassosi Hilmy, 1949 (family Cladorchiidae) from dugong [Dugong dugong (Müller)] in Australia and Diplodiscus subclavatus (Pallas, 1760) (family Diplodiscidae) from marsh frog [Pelophylax ridibundus (Pallas) (formerly Rana ridibunda)] in Bulgaria. More recently, the interrelationships of paramphistomes were assessed by Sokolov et al. (2016) using molecular data, but only a single cladorchiid from fish, Amurotrema dombrowskajae Achmerov, 1959, a parasite of the grass carp, Ctenopharyngodon idella (Valenciennes), in the Palaearctic region, was included in this analysis.

Based on available data, we cannot confirm the monophyletic status of the family Cladorchiidae, whereas two of its subfamilies, Dadayiinae and Kalitrematinae, appeared as non-monophyletic. However, molecular data for members of other subfamilies of the Cladorchiidae are needed before any change in subfamilial classification is proposed. The same applies to the validity of some morphologically well-distinct, but genetically closely related genera, such as Goeldamphistomum Pantoja, Scholz, Luque et Jones, 2018 and Iquitostrema Pantoja, Scholz, Luque et Jones, 2018, because their intergeneric nucleotide divergence was the same as, or lower than, intrageneric (interspecific) divergence in some genera.

Using molecular data, it was possible to confirm the distinctions between morphologically similar species, such as Pseudocladorchis nephrodorchis and the new species P. romani, and three species of Dadaytrema. In contrast, some morphologically distinct species of different genera appeared to be closely related, e.g. two recently described species of two newly erected genera from Peru, Goeldamphistoma and Iquitostrema. They are conspicuously different from each other in several morphological characters, including the size and robustness of the body, the size, shape and type of the acetabulum, the pharyngeal type, the position of the testes relative to the caeca and to each other, the extent of the uterine coils relative to the caeca, and the distribution of vitelline fields (see Pantoja et al. 2018). Some previous studies have also revealed that 28S rDNA may not help to differentiate closely related species (Hwang and Kim 1999, Ghatani et al. 2014), but this marker made it possible to differentiate two species of Pseudocladorchis in the present study (Fig. 6).

Neotropical cladorchiids are revealed to be monophyletic, with three non-Neotropical cladorchiids, namely A. dombrowskajae from Russia, Helostomatis cf. helostomatis from Thailand and Pisciamphistoma stunkardi from USA, representing their sister clade. The first species is native to the Far East of Russia and was introduced with carp to Central Asia, East and Central Europe (Chen 1985, Sokolov et al. 2016). It is more closely related to $H$. cf. helostomatis from the Indomalayan region, both taxa being a sister of the Nearctic P. stunkardi. Manter (1963) proposed that this parasite of centrarchids in North America is not closely related to cladorchiids from Brazil, having originated from a marine ancestor.

McClelland (1957) commented on the morphological similarity between Brevicaecum niloticum McClelland, 1957 (African) and Kalitrema kalitrema Travassos, 1933 (South American), but also accepted the significant morphological differences between the two monotypic genera. Many more taxa have been described in the South American fauna since 1957. It seems that geographical isolation can be a factor in divergence and it may have been significant, although it was not necessarily a defining factor. Presumably, in the event of a common origin, there will have been many extinction events. In fact, South American and African cladorchiids share similar hosts (siluriform and characiform fishes) (Manter 1963, Jones 2005b, Thatcher 2006). Unfortunately, molecular data are not available for any African cladorchiid from freshwater fish to have a better insight into the evolutionary history of the group.

Over-all, molecular data reveal less strict host specificity of most species because the same species occurred in fishes of different species, genera, families or even orders (Characiformes and Siluriformes). For example, Dadayius marenzelleri occurs in auchenipterids and serrasalmids, Dadaytrema minimum in auchenipterids, doradids, pimelodids and serrasalmids, and Dadaytrema oxycephalum in three families of catfishes (Auchenipteridae, Doradidae and Pimelodidae) and two families of characiforms (Characidae and Serrasalmidae). Molecular data also confirmed the wide geographical distribution of several species that occur in both principal river basin in South America, i.e. the Amazon and Paraná River basins (three species of Dadaytrema and Doradamphistoma parauchenipteri).

Most cladorchiids from freshwater fishes in South America occur in characiform fishes, but the present extensive material collected throughout Brazil and in Peru also originated to a large extent from catfishes, with the highest number of species (and the highest intensity of infection) found in doradids. The number of cladorchiids found in auchenipterids and pimelodids was considerably lower and very few paramphistomes occurred in cichlids, but the specimens found in Heros sp. represented a new species. Despite the extensive research of V.E. Thatcher in the Brazilian Amazonia in the two last decades of the 20th century, this group of fish paramphistomes remains insufficiently known. This has been demonstrated by Pantoja et al. (2018) who described three new species in two new genera based on material from Peruvian Amazonia, and by the high number of new host and geographical records presented here. The description of another three new species in the present paper increases the total diversity of cladorchiids in freshwater fish in South America to 38 species, confirming the family as dominant in the Neotropical region (Thatcher 2006, Choudhury et al. 2016). 
Acknowledgements. Two reviewers provided helpful suggestions. The authors are indebted to Roman Kuchta (Czech Republic), the late Martin Mortenthaler (Peru), Aldenice Pereira, Angélica Lago, Felipe Bisaggio Pereira, Janio Carneiro, Juliana Moreira, Luiz Eduardo Tavares, Marcos Tavares, Maria Catarina Moraes, Naraiana Taborda, Philippe Alves, Ricardo Takemoto (all Brazil), C. Cruses, J. Chero (Peru), Chris T. McAllister and Anindo Choudhury (both USA) for their invaluable help with collection and dissection of fish. Thanks are also due to Célio Ubirajara Magalhães Filho, curator of the Helminthological Collection of the Instituto Nacional de Pesqui- sas do Amazonas (INPA), Manaus, Brazil, and Helmut Sattmann and Stefan Szeiler, Invertebrate Collection of the Natural History Museum (ZMW), Vienna, Austria, for enabling a study of type and voucher specimens of cladorchiids. Daniel Barčák (Košice) provided specimens of Helostomatis cf. helostomatis for molecular study. Douglas McIntosh (UFRRJ) provided support on sequencing of part of samples. This study was financially supported by the Czech Science Foundation (project No. P505/12/G112) and Institute of Parasitology, BC CAS (institutional support RVO 60077344).

\section{REFERENCES}

ANDERSON G.R., BARKER S.C. 1998: Inference of phylogeny and taxonomy within the Didymozoidae (Digenea) from the second internal transcribed spacer (ITS2) of ribosomal DNA. Syst. Parasitol. 41: 87-94.

Bowles J., Blair D., McManus D.P. 1995: A molecular phylogeny of the human schistosomes. Mol. Phyl. Evol. 2: 103-109.

Choudhury A., Aguirre-Macedo M.L., Curran S.S., Ostrowski de NúÑez M., Overstreet R.M., Pérez-Ponce de LeÓN G., Santos C.P. 2016: Trematode diversity in freshwater fishes of the Globe II: 'New World'. Syst. Parasitol. 93: 271-282.

DAdAY F. 1907: In Südamerikanischen Fischen lebend Trematoden-Arten. Zool. Jahrb., Abt. Syst., Geogr. Biol. Tiere 24: 469 590.

Darriba D., Taboada G.L., Doallo R., Posada D. 2012: jModelTest 2; more models, new heuristics and parallel computing. Nat. Meth. 9: 772-772

Diesing K.M. 1836: Monographie der Gattungen Amphistoma and Diplodiscus. Annal. Wiener Mus. Naturgesch. 1: 235-260.

EduARdo S.L. 1982: The taxonomy of the family Paramphistomidae Fischoeder, 1901 with special reference to the morphology of species occurring in ruminants I. General considerations. Syst. Parasitol. 4: 7-57.

Froese R., Pauly D. (Eds.) 2018: FishBase. World Wide Web electronic publication. http://Www.fishbase.org.

Ghatani S., Shylla J. A., Bishnupada R., Tandon V. 2014: Multilocus sequence evaluation for differentiating species of the trematode Family Gastrothylacidae, with a note on the utility of mitochondrial COI motifs in species identification. Gene 548: $277-284$.

Heyneman D., Brenes R.R., Diaz-Ungria C. 1960: Trematodos de Venezuela II. Algunos trematodos de peces, reptiles y aves con descripción de una nueva especie del género Lubens. Mem. Soc. Cienc. Nat. La Salle 20: 138-149.

Hwang U. W., Kim W. 1999. General properties and phylogenetic utilities of nuclear ribosomal DNA and mitochondrial DNA commonly used in molecular systematics. Korean J. Parasitol. 37: $215-228$

Jones A. 2005a: Superfamily Paramphistomoidea Fischoeder, 1901. In: A. Jones, R.A. Bray and D.I. Gibson (Eds.), Keys to the Trematoda. Volume 2. CAB International \& The Natural History Museum, Wallingford, pp. 221-227.

Jones A. 2005b: Family Cladorchiidae Fischoeder, 1901. In: A Jones, R.A. Bray and D.I. Gibson (Eds.), Keys to the Trematoda. Volume 2. CAB International \& The Natural History Museum, Wallingford, pp. 257-317.

Katoh K., Standley D.M. 2013: MAFFT multiple sequence alignment software version 7 : improvements in performance and usability. Mol. Biol. Evol. 30: 772-780.

Kuchta R., CaIRa J.N. 2010: Three new species of Echinobothrium (Cestoda: Diphyllidea) from Indo-Pacific stingrays of the genus Pastinachus (Rajiformes: Dasyatidae). Folia Parasitol. 57: 185-196.

Lacerda A.C.F., Takemoto R.M., Pavanelli G.C. 2003: A new species of Dadayius Fukui, 1929 (Digenea: Cladorchiidae), parasite of the intestinal tract of Metynnis maculatus (Kner, 1858)
(Characidae) from the upper Paraná River floodplain, Brazil. Acta Sci., Biol. Sci. 25: 283-285.

Laidemitt M.R., Zawadzki E.T. Brant S.V., Mutuku M.W., MkJi G.M., Loker E.S. 2017: Loads of trematodes: discovering hidden diversity of paramphistomoids in Kenyan ruminants. Parasitology 144: 131-147.

Lopes L.P.C., Karling L.C., Takemoto R.M., Rossoni F., FerReira E.J.G., PAVAnelli G.C. 2011: A new species of Dadayius Fukui, 1929 (Digenea: Cladorchiidae), parasite of Symphysodon aequifasciatus Pellegrin, 1904 (Perciformes: Cichlidae) from the Purus River, Amazon, Brazil. Helminthologia 48: 200-202.

Lotfy W.M., Brant S.V., Ashmawy K.I., Devkota R., Mkoj G.M., LoKer E.S. 2010. A molecular approach for identification of paramphistomes from Africa and Asia. Vet. Parasitol. 174: $234-240$.

LUNASCHI L.I. 1987: Helmintos parasitos de peces de agua dulce de la Argentina VI. Sobre uma nueva espécie del genero Microrchis Daday, 1907 (Trematoda - Paramphistomidae). Neotropica 33: 37-40.

LUNASCHI L.I. 1989: Helmintos parasitos de peces de agua dulce de la Argentina. VII. Acerca de dos nuevas espécies de paranfistómidos (Trematoda - Paramphistomidae). Neotropica 35: $35-42$.

Luton K., Walker D., Blair D. 1992: Comparisons of ribosomal internal transcribed spacers from two congeneric species of flukes (Platyhelminthes: Trematoda Digenea). Mol. Biochem. Parasitol. 56: 323-327.

Manter H.W. 1963: The zoogeographical affinities of trematodes of South American freshwater fishes. System. Biol. 12: 45-70.

MCClelland W.F.J. 1957: Two new genera of amphistomes from Sudanese freshwater fishes. J. Helminthol. 4: 247-256

NÄSMARK K.E. 1937: A revision of the trematode family Paramphistomidae. Zool. Bidrag Uppsala 16: 301-565.

Olson P.D., Cribb T.H., Tkach V.V., Bray R.A., Littlewood D.T.J. 2003: Phylogeny and classification of the Digenea (Platyhelminthes: Trematoda). Int. J. Parasitol 33: 733-755.

Pantoja C., Scholz T., Luque J.L., Jones A. 2018: New genera and species of paramphistomes (Digenea: Paramphistomoidea: Cladorchiidae) parasitic in fishes from the Amazon basin in Peru. Syst. Parasitol. 95: 611-624.

Rambaut A., Suchard M.A., Xie D., Drummond A.J. 2014 Tracer v1.6, World Wide Web electronic publication, http://beast. bio.ed.ac.uk/Tracer

Ronquist F., Teslenko M., Van Der Mark P., Ayres D.L., Darling A., Höhna S., Larget B., Liu L., Suchard M. A., Huelsenbeck J. P. 2012: Mr.Bayes 3.2: Efficient Bayesian phylogenetic inference and model choice across a large model space. Syst. Biol. 61: 539-542.

SEY O. 1988: Scope of and proposal for systematics of the Amphistomida (Lühe, 1909) Odening, 1974. Parasitol. Hung. 21: 17-30.

SEY O. 1991: CRC Handbook of the Zoology of Amphistomes. CRC Press, Boca Raton, Florida, 480 pp.

SEY, O. 2005: Keys to the Identification of the Taxa of the Amphistomes (Trematoda, Amphistomida). Regional Centre of the 
Hungarian Academy of Sciences, Veszprem (MTA VEAB)/ University of Pecs, Pecs, 120 pp.

Sokolov S.G., Lebedeva, D.I., Kalmykov A.P. 2016: Phylogenetic position of trematode Amurotrema dombrovskajae Achmerow, 1959 (Paramphistomoidea: Cladorchiidae) based on partial 28S eDNA nucleotide sequences. Helminthologia 53: 161-164.

STUNKARD H.W. 1925: The present status of the amphistome problem. Parasitology 17: 137-148.

Thatcher V.E. 1979: Paramphistomidae (Trematoda: Digenea) de peixes de agua doce: dois novos gêneros de Colombia e uma redescrião de Dadaytrema oxycephala (Diesing, 1936) Travassos, 1934 da Amazonia. Acta Amazon. 9: 203-208.

Thatcher V.E. 1992: Two new genera of Paramphistomidae (Trematoda, Digenea) from freshwater fish of Rondônia State, Brazil. Mem. Inst. Oswaldo Cruz 87: 287-291.

Thatcher, V. E. 1999. Surface morphology of some amphistomes (Trematoda) of Amazonian fishes and the description of a new genus and species. Acta Amazon. 29: 607-614.

Thatcher V.E. 2006: Amazon Fish Parasites. Second edition. Aquatic Biodiversity in Latin America. Volume 1. Pensoft, Sofia \& Moscow, 508 pp.

Thatcher V.E., JÉGU M. 1996: Intestinal helminths as population markers of the Amazonian fish Mylesinus paraschomburgkii, with descriptions of five new genera and seven new species of trematodes. Amazoniana 14: 143-156.

Thatcher V. E., JÉGU M. 1998: Amphistomes as species markers of the serrasalmid fish, Myleus ternetzi (Norman) from French
Guiana, with descriptions of two new species and one new genus. Amazoniana 15: 103-112.

Thatcher V. E., Sey O., JÉGu M. 1996: New amphistome (Trematoda) genera and species from Amazonian serrasalmid fishes, Myleus (Myloplus). Acta Zool. Acad. Sci. Hung. 42: 261-270.

Tkach V., Pawlowski J., Mariaux J. 2000: Phylogenetic analysis of the suborder Plagiorchiata (Platyhelminthes, Digenea) based on partial 1srDNA sequences. Int. J. Parasitol. 30: 83-93.

Travassos L. 1931: Notas helmintolojicas. Bol. Biol. 19: 148-149.

Utuk A.E., PISkin F.C. 2012: Molecular detection and characteriation of goat isolate of Taenia hydatigena in Turkey. Sci. World J. 2012: $1-4$.

VAZ Z. 1932: Contribuição ao conhecimento dos trematóides de peixes fluviais do Brasil. Inaugural Dissertation, São Paulo, 47 pp.

Vélez J., Hirzmann J., Lange M. K., Chaparro-Gutiérrez J. J., Taubert A., Hermosilla C. 2018: Occurrence of endoparasites in wild Antillean manatees (Trichechus manatus manatus) in Colombia. Int. J. Parasitol. Parasites Wildl. 7: 54-57.

Vicente J.J., Santos E., Souza S.V. 1978: Helmintos de peixes do litoral norte fluminense - II. Mem. Inst. Oswaldo Cruz 72: $173-180$.

Yamaguti S. 1958: The Digenetic Trematodes of Vertebrates. Parts I \& II. Interscience Publ., New York \& London, xi + 1575 pp.

ZwICKL D.J. 2006: Genetic algorithm approaches for the phylogenetic analysis of large biological sequence datasets under the maximum likelihood criterion. Thesis, University of Texas, Austin, $115 \mathrm{pp}$

Cite this article as: Pantoja C., Scholz T., Luque J.L., Jones A. 2019: First molecular assessment of the interrelationships of cladorchiid digeneans (Digenea: Paramphistomoidea), parasites of Neotropical fishes, including descriptions of three new species and new host and geographical records. Folia Parasitol. 66: 011. 